\title{
Razvoj znanstvenog polja metalurgije u Republici Hrvatskoj u razdoblju od 1960. do 2020. godine
}

\author{
M. Gojić
}

Metalurški fakultet Sveučilišta u Zagrebu, Aleja narodnih heroja 3, 44000 Sisak

\begin{abstract}
Sažetak
U ovom radu naveden je razvoj znanstvenog polja metalurgije u području tehničkih znanosti u Republici Hrvatskoj (RH) u razdoblju od 1960. do 2020. godine. Razvoj metalurgije odvijao se na Metalurškom odjelu (1960. - 1974.) i Metalurškom inženjerstvu Tehnološkog fakulteta Sveučilišta u Zagrebu (1974. - 1978.), Institutu za lake metale u Zagrebu (1949. - 1968.), Institutu za metalurgiju u Sisku (1961. - 1978.), Metalurškom fakultetu u okviru Željezare Sisak (1979. - 1991.) i na Metalurškom fakultetu kao samostalnoj sastavnici Sveučilišta u Zagrebu (1991. -). Razvoj polja metalurgije usko je vezan s metalurškom industrijom u RH (Željezara Sisak, Tvornica lakih metala Šibenik, brojne ljevaonice itd.) i stručnim knjižnicama. Prikazana je nastavna, znanstveno-istraživačka i stručna aktivnost te izdavačka i publicistička djelatnost u znanstvenom polju metalurgije. Naveden je i kratki prikaz doprinosa polju metalurgije i drugih visokoškolskih institucija i stručnih društava. U tom razdoblju (do 31. 12. 2019. godine) stečena su 763 akademska zvanja i 34 akademska stupnja doktora znanosti iz polja metalurgije na Sveučilištu u Zagrebu i u RH. U razdoblju 1960. - 2020. objavljeno je više od 3000 znanstvenih i stručnih radova u domaćim i međunarodnim časopisima i zbornicima međunarodnih i domaćih konferencija. Kao rezultat stručnih aktivnosti izrađeno je više od 1000 studija i elaborata, velik broj stručnih izvještaja za gospodarske subjekte iz metalurgije i srodnih znanstvenih polja, registrirano je oko 20-ak patenata itd. U tom razdoblju u polju metalurgije tiskano je nekoliko monografija, više od 50 knjiga i sveučilišnih udžbenika, sedam zbornika cjelovitih radova (1999. - 2006.) i jedanaest zbornika sažetaka (2008. - 2019.) međunarodnog savjetovanja ljevača, brojne sveučilišne i interne skripte itd.
\end{abstract}

\section{Ključne riječi}

Metalurgija, Metalurški odjel, Institut za metalurgiju, Institut za lake metale, Metalurški fakultet Sveučilišta u Zagrebu

\section{Uvod}

Razvoj znanstvenog polja metalurgije u području tehničkih znanosti u razdoblju 1960. - 2020. u uskoj je vezi i s razvojem Metalurškog fakulteta, kao jedinom visokoškolskom i znanstvenom institucijom koja se bavi nastavnom, znanstveno-istraživačkom i stručnom djelatnošću u području tehničkih znanosti u polju metalurgije na Sveučilištu u Zagrebu i u Republici Hrvatskoj (RH). U tom razdoblju razvoj polja metalurgije odvijao se, ovisno o društvenim okolnostima, kroz šest različitih etapa, odnosno organizacijskih oblika i to na: Metalurškom odjelu (1960. - 1974.) i Metalurškom inženjerstvu u Sisku (1974. - 1978.) Tehnološkog fakulteta Sveučilišta u Zagrebu, Institutu za lake metale u Zagrebu (1949. - 1968.), Institutu za metalurgiju u Sisku (1961. - 1978.), Metalurškom fakultetu u okviru Željezare Sisak (1979. - 1991.) i na Metalurškom fakultetu kao samostalnoj sastavnici Sveučilišta u Zagrebu (1991. -). Treba napomenuti da su, pored navedenih institucija iz Siska, doprinos razvoju polja metalurgije dali i daju današnji tehnički fakulteti u RH: Fakultet strojarstva i brodogradnje (FSB) iz Zagreba (1956.), Fakultet elektrotehnike, strojarstva i brodogradnje (FESB) iz Splita (1960.), Tehnički fakultet (TF) iz Rijeke (1960.) i Strojarski fakultet (SF) iz Slavonskog Broda (1962.), koji su u okviru dijela svojih zavo-

*Prof. dr. sc. Mirko Gojić, red. prof. u trajnom zvanju e-pošta: gojic@simet.hr da, katedri i laboratorija aktivni u pojedinim znanstvenim disciplinama usko vezanim s poljem metalurgije (lijevanje, plastična prerada, toplinska obrada i zavarivanje metalnih materijala itd.). Nastava iz ljevarstva i oblikovanja metala deformiranjem (u obliku pojedinačnih predmeta) odvija se i na svim navedenim fakultetima od njihova osnivanja. Oni sudjeluju i u istraživačkom i stručnom radu, primarno iz ljevarstva i plastične deformacije te u organizaciji seminara iz ljevarstva. Također, pojedini instituti i/ili laboratoriji u okviru velikih gospodarskih subjekata: Željezara Sisak, Tvornica lakih metala (TLM) Šibenik, Institut "Đure Đakovića" Slavonski Brod, Institut Jugoturbine Karlovac itd., dali su određen doprinos razvoju polja metalurgije.

Potkraj 1950-ih godina javila se potreba za visokoškolskim kadrovima metalurške i kemijsko-tehnološke struke zbog brzog gospodarskog razvoja. To se primarno odnosilo na metaluršku struku jer se u RH nisu obrazovali kadrovi tog profila niti na jednoj razini. Tadašnje visokoškolsko obrazovanje metalurškog smjera u Beogradu i Ljubljani nije moglo dati potreban broj diplomiranih inženjera. Na primjer, na Metalurškom odjelu Fakulteta za rudarstvo, metalurgiju i kemijsku tehnologiju u Ljubljani je 1958. i 1959. godine metalurgiju diplomirao po 21 student godišnje. Prema podatcima Udruženja jugoslavenskih željezara (UJŽ) u poduzećima crne metalurgije 1956. godine bilo je ukupno 106 inženjera metalurškog smjera uz istodobni nedostatak 187 inženjera. ${ }^{1}$ Za razdoblje 1957. - 1961. iskazana 
je potreba za 276 inženjera metalurgije za gospodarske metalurške subjekte bivše Jugoslavije. Tadašnja slaba dostupnost visokoobrazovanog kadra sisačkoj industriji može se ilustrirati podatcima prema kojima je 1960. godine, tj. u doba osnivanja Odjela u Sisku, Željezara Sisak imala ukupno 114 zaposlenika s visokom i višom stručnom spremom² (od kojih je 68 inženjera svih struka), od kojih je nekoliko diplomiranih inženjera metalurgije i 9 diplomiranih inženjera kemije, a Rafinerija nafte Sisak imala je 8 diplomiranih inženjera kemije. ${ }^{1}$ Stoga su Željezara Sisak i Rafinerija nafte Sisak pokazali velik interes za osnivanje visokoškolske ustanove u Sisku za izobrazbu metalurškog i kemijsko-tehnološkog kadra. ${ }^{3}$ Željezara Sisak je u to vrijeme po broju zaposlenih i obujmu proizvodnje bila treće (iza željezara Zenica i Jesenice) poduzeće crne metalurgije u bivšoj Jugoslaviji, praćeno visokom fluktuacijom radne snage, posebno visokostručnog kadra. Prve aktivnosti u svezi s ustrojstvom visokoškolske nastave u Sisku započele su u Zagrebu sredinom 1958. godine održavanjem sastanaka na tu temu. ${ }^{4} \mathrm{Na}$ kraju je prevagnuo stav da se osnuju odjeli u Sisku Tehnološkog fakulteta s Metalurškim odjelom kao jednim od odjela. Osim realnog interesa gospodarskih subjekata za visokoškolskim kadrovima, tada je bila i opća društvena klima u Sisku za ustrojstvom visokoškolskog obrazovanja. Tome je vjerojatno doprinijela i odluka Saveznog izvršnog vijeća (SIV) iz proljeća 1959. godine, na temelju brojnih zamolbi UJŽ-a, da se pristupi rekonstrukciji postojećih i izgradnji novih metalurških kapaciteta. ${ }^{5}$ Također je važna činjenica, koja je išla u prilog pokretanju visokoškolske nastave u Sisku, o postojanju tendencija za decentralizacijom visokoškolskog sustava izvan Zagreba, pri čemu se stvaraju preduvjeti za otvaranje tehničkih studija i u značajnim industrijskim središtima (Rijeka, Split itd.). Analitička procjena radnih mjesta pokazala je da je kvalifikacijska struktura u Željezari Sisak bila nezadovoljavajuća i sa stajališta visokostručnih kadrova. Od 5587 zaposlenika u 1958. godini samo je 1,6 \% imalo visokoškolsko obrazovanje. ${ }^{5}$ Prethodno navedene činjenice dovele su do toga da organizirana cjelovita nastavna, znanstvena i stručna djelatnost iz polja metalurgije u RH započne akad. god. 1960./61. osnivanjem Metalurškog odjela u Sisku Tehnološkog fakulteta Sveučilišta u Zagrebu. U razdoblju 1960. - 2020. nastavni planovi i programi mijenjali su se u skladu s razvojem struke, potrebama gospodarstva itd. ${ }^{6}$ Cilj tih promjena bila je želja za pružanjem većih specijaliziranih znanja i stjecanjem širih kompetencija u znanstvenim granama i disciplinama u polju metalurgije. Od 1960. do 2020. godine razvoj polja metalurgije nezamisliv je bez doprinosa velikog broja znanstveno-istraživačkih i stručnih projekata financiranih iz različitih izvora: Savezni fond za naučni rad, Republički fond za naučni rad (od 1970.), Opće udruženje crne metalurgije Jugoslavije (OUCMJ), SIZ (Samoupravna interesna zajednica) za znanost SR Hrvatske (1978. - 1990.), Fond za znanstvenoistraživački rad Željezare Sisak (1979. - 1991.), nadležno ministarstvo (od 1991.), međunarodni znanstveni projekti i infrastrukturni projekti u okviru Europskog fonda za regionalni razvoj (EFRR), gospodarski subjekti, razvojni projekti Sveučilišta u Zagrebu, istraživački projekti Hrvatske zaklade za znanost (HRZZ), kratkoročne (jednogodišnje) financijske potpore i/ ili institucijski projekti financirani od Sveučilišta u Zagrebu itd. Osim toga, razvoju polja metalurgije pripomoglo je ustrojavanje knjižnica, publicistička i izdavačka djelatnost, organiziranje savjetovanja i simpozija, znanstveno-stručnih seminara i radionica itd. Ovaj je pregled napisan na temelju dostupnih relevantnih referencija, ali uključujući i osobno 35-godišnje izravno sudjelovanje i svjedočenje u nekim djelatnostima u polju metalurgije u različitim oblicima.

\section{Metalurški odjel u Sisku Tehnološkog fakulteta Sveučilišta u Zagrebu (1960. - 1974.)}

Sustavno organizirana nastavna, znanstveno-istraživačka i stručna aktivnost iz znanstvenog polja metalurgije započela je akad. god. 1960./61. na Metalurškom odjelu (jedan od dva odjela: Metalurški odjel i Tehnološko-pogonski odjel za naftu) u Sisku Tehnološkog fakulteta na temelju Zakona koji je donio Sabor NR Hrvatske 7. srpnja 1960. godine. ${ }^{7}$ Odjeli Tehnološkog fakulteta u Sisku započeli su rad u adaptiranim prostorijama nedovršene zgrade Školskog centra za metalce (ŠCM) na Viktorovcu (slika 1), koju im je na raspolaganje ustupila Skupština općine Sisak. ${ }^{8}$ Osnivanje odjela u Sisku 1960. godine poduprli su najznačajniji gospodarski subjekti Siska kao i predstavnici lokalne vlasti. ${ }^{9}$ Veliku pomoć studiju u Sisku pruža matični Tehnološki fakultet izravnim sudjelovanjem u nastavi, ustrojstvom laboratorija i mineraloške zbirke te podizanjem znanstveno-nastavnog podmlatka. $U$ tome se posebno ističu akademici Miroslav Karšulin (1904. - 1984.) i Luka Marić (1889. - 1979.), prof. dr. sc. Marijan Laćan (1919. - 1980.) i prva doktorica tehničkih znanosti (1928.) u RH prof. dr. sc. Vjera Marjanović-Krajovan (1898. - 1988.). Veliku pomoć u nastavi, a kasnije i u radu odjela u Sisku oduvijek je pružao i akademik Ivan Jurković (1917. - 2014.), kasnije rektor Sveučilišta u Zagrebu (1979. - 1982.) i predsjednik Republičkog savjeta za obrazovanje, znanost i kulturu (1978. - 1982.). Od tzv. "domaćih kadrova" najznačajniju ulogu u osnivanju i početku rada odjela u Sisku imali su: honorarni docent Tehnološkog fakulteta Vladimir Logomerac (1914. - 1980.), u to vrijeme rukovoditelj Sektora za istraživanje Željezare Sisak, i glavni inženjer Zeljezare Sisak Lujo Chloupek (1901. - 1980.). Osnivanje odjela u Sisku poduprli su, kao predstavnici najznačajnijih gospodarskih subjekata i lokalne zajednice: direktor Željezare Sisak Norbert Veber (1912. - 1974.) i direktor Rafinerije nafte Sisak Ante Milković (1917. - 1999.) te predsjednik

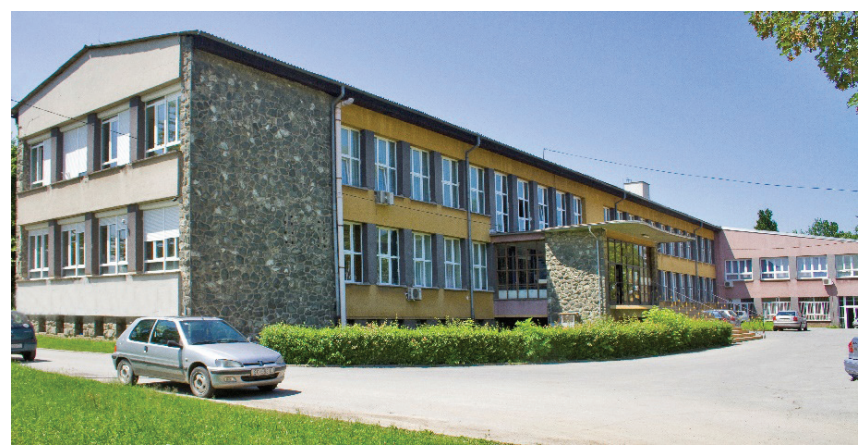

Slika 1 - Glavna zgrada Metalurškog fakulteta u Sisku (2010.)

Fig. 1 - Main building of the Sisak Faculty of Metallurgy (2010) 
(1958. - 1963.) Skupštine općine Sisak Srećko Steinburg $(1918 .-2000 .)^{9}$

Na početku se rad odjela Tehnološkog fakulteta u Sisku odvijao putem šest zavoda i dva kabineta (ukupna površina oko $2700 \mathrm{~m}^{2}$ ). Od akad. godine 1964./65. djelatnosti Metalurškog odjela odvijale su se kroz tri katedre: Katedra za kemiju i fiziku, Katedra za strojarstvo i Katedra za metalurgiju. Nastava iz polja metalurgije u Sisku kontinuirano se odvijala na II. stupnju (diplomirani inženjer metalurgije), a po potrebi na I. (inženjer metalurgije) od akad. god. 1967./67. i III. stupnju (poslijediplomski magistarski studij metalurgije) od akad. god. 1965./66. Prvi nastavni plan i program studija metalurgije na II. stupnju koncipiran je akad. god. 1960./1961. kao opći četverogodišnji redoviti studij bez smjerova. ${ }^{6}$ Prve dvije godine studija utemeljene su na fundamentalnim predmetima (Viša matematika I i II, Tehnička fizika, Anorganska kemija s tehnologijom, Analitička kemija I, II i III, Fizikalna kemija I i II itd.) i predmetima bitnim za metalurgiju: Uvod u metalurgiju i osnove oplemenjivanja ruda, Mineralogija i osnovi rudnih ležišta, Termodinamika I i II, Mehanika I i II itd. Kroz skupinu stručnih metalurških predmeta na 3. i 4. godini (Metalurgija željeza i čelika I i II, Metalurške peći s projektiranjem I i II, Metalurško tehnološko računanje, Ljevarstvo, Tehnologija valjanja, kovanja i vučenja I i II, Ispitivanje i kontrola materijala, Termička obrada i specijalni čelici itd.) studenti se poučavaju o dobivanju sirovog željeza i čelika, metalurškim pećima, proizvodnim tehnologijama lijevanja i plastične prerade, toplinskoj obradi i ispitivanju materijala itd.

Nastavnici stručnih metalurških predmeta, osim profesora L. Chloupeka i V. Logomerca, kao vanjski suradnici iz Željezare Sisak, bili su: prof. Pavle Pavlović, dr. h. c. (1919. - 2001.), v. predavač Zdenka Lončar, dipl. ing. (1924. - 1987.) i predavač Ivo Lipovac, dipl. ing. (1928. - 1998.). Prof. Rajko Lipold (1908. - 2004.) s Mašinskog fakulteta Univerziteta u Sarajevu i prof. Franc Širca (1922. - 2005.) s Fakulteta za rudarstvo, metalurgiju i kemijsku tehnologiju iz Ljubljane sudjelovali su u nastavi kao vanjski suradnici. ${ }^{9}$ Prvi profesori s odjela u Sisku razvijali su i podizali nastavni kadar od najboljih studenata s oba odjela u Sisku. Profesori stručnih metalurških predmeta imali su praktičnog, istraživačkog, nastavnog i publicističkog iskustva jer su i od ranije imali objavljene radove u časopisima i/ili izrađene studije i elaborate iz polja metalurgije. Veliku pomoć u nastavi kao nositelji predmeta iz polja strojarstva i elektrotehnike pružali su iskusni praktičari i vanjski suradnici (kao predavači) iz Željezare Sisak (Alirizah Dorocić, dipl. ing.; Dobrašin Vlahović, dipl. ing., itd.) i Rafinerije nafte Sisak (Mladen Mlinarić, dipl. ing.; Dragutin Kovačić, dipl. ing. itd.).

Prof. Lujo Chloupek je 1923. godine diplomirao na Metalurškom odjelu Visoke rudarske škole u Pribramu (Češka), a praktična metalurška iskustva stjecao je radeći u željezarama Dovhoje (Češka), Vareš, Zenica, Sisak itd. Bavio se istraživanjima iz područja proizvodnje sirovog željeza i osnovnih metalurških sirovina, a kao honorarni nastavnik predavao je na Tehnološkom fakultetu u Beogradu (akad. god. 1950./51.) predmet: Projektiranje visokih i SM-peći. Autor je udžbenika Proizvodnja sirovog gvožđa (1954.). Među njegovim objavljenim radovima u časopisu Teška industrija može se istaknuti rad: Priprema i topljenje vareških ruda u visokoj peći obzirom na domaći koks (1951.) itd.
Prof. V. Logomerac diplomirao je 1938. godine na Kemijsko-inženjerskom odsjeku Tehničkog fakulteta u Zagrebu. Bavio se iskorištavanjem siromašnih boksita, laterita i crvenog mulja te je bio i "pionir" u metalurškoj pripremi rudnih sirovina itd. Metalurška iskustva stjecao je radeći u željezarama Zenica, Vareš i Sisak, a u Institutu "Boris Kidrič" u Vinči je radio na problematici urana (1952. - 1955.) itd. Od akad. god. 1951./52. bio je i honorarni nastavnik predmeta Metalurgija željeza na Kemijsko-tehnološkom odsjeku Tehničkog fakulteta u Zagrebu. Izradio je više elaborata, kao npr. Prerada crvenog mulja (1950.), objavio je u časopisu Kemija u industriji rad: Problem pripreme branda za iskorištenje u visokim pećima (1960.) itd.

Prof. Pavle Pavlović diplomirao je 1945. godine na Bergakademie Freiberg (Njemačka) i bio je 1945. godine pomoćni asistent poznatog njemačkog metalurga prof. Eduarda Maurera (1886. - 1969.) na Institutu za željezo i čelik Bergakademie Freiberg. Metalurška iskustva stjecao je radeći u željezarama Smederevo, Zenica i Sisak. U časopisu Tehnika RMG objavio je rad: Stanje proizvodnje čelika u Velikoj Britaniji - Osvrt na britansku praksu konstrukcije SM peći (1959.) itd.

Viši predavač Zdenka Lončar, dipl. ing., diplomirala je 1952. godine na Odjelu za metalurgiju na Fakultetu za rudarstvo i metalurgiju Tehničke visoke škole u Ljubljani. Metalurška iskustva stjecala je radeći u ljevaonici Željezare Sisak. U časopisu Ljevarstvo objavila je radove: Kokile za čeličane (1957.), Osvajanje izradbi jezgri za kokile od cementnog pijeska (1958.) itd. Predavač Ivo Lipovac, dipl. ing., diplomirao je 1954. godine na Kemijsko-tehnološkom odjelu Tehničkog fakulteta u Zagrebu. Metalurška iskustva stjecao je radeći od 1956. godine u Odjelu Tehničke kontrole Željezare Sisak. U časopisu Metalurgija objavio je rad: Određivanje granice istezanja na povišenim temperaturama čelika St 35-8 za kotlovske cijevi (1962.) itd.

Prof. Rajko Lipold diplomirao je iz polja metalurgije 1932. godine na današnjem RWTH Sveučilištu u Aachenu (Njemačka). Uže područje istraživanja je plastična deformacija metalnih materijala i valjaoničarstvo. Predavao je predmete iz područja plastične deformacije na Mašinskom fakultetu Univerziteta u Sarajevu. Svoja metalurška iskustva stjecao je kao savjetnik i suradnik pri izgradnji valjaoničarskih kapaciteta u željezarama u Skopju, Zenici, Jesenicama itd. Prof. Franc Širca diplomirao je 1949. godine na Talioničkom odjelu Tehničkog fakulteta u Ljubljani. Primarno se bavio istraživanjem u području fizike metala, primarno metalografijom. Metalurška iskustva stjecao je na specijalizaciji u Francuskoj (1951. - 1952., 1955. - 1956.) te je predavao (1959.) i na rudarskoj akademiji u Chlaustalu (Njemačka). U časopisu Rudarsko-metalurški zbornik objavio je rad: Vpliv alfagenih elementov na difuzijo bakra $v$ železo gama (1959.) itd.

Od 49 studenata metalurgije upisanih u akad. godini 1960./61. Željezara Sisak stipendirala je 28 studenata. ${ }^{10}$ Većina studenata došla je na studij iz radnog odnosa $s$ radnih mjesta tehničara i tzv. asistenata iz neposredne proizvodnje. U to vrijeme prijelaz iz I. u II. studijsku godinu iznosio je $71 \%$, a prijelaz iz II. u III. studijsku godinu iznosio je $65 \%{ }^{1}$ Vrijeme trajanja studija studenata metalurgije koji su diplomirali u akad. god. 1964./1965. 
bilo je 4,5 godine. ${ }^{3}$ Očito da je to bio rezultat velike motiviranosti studenata i angažiranosti nastavnika. Prvi student koji je diplomirao metalurgiju na Metalurškom odjelu je Mladen Haramina, koji je pod mentorstvom izv. prof. Luje Chloupeka diplomirao 5. prosinca 1964. godine na temi pod naslovom: Ispitivanje potisne peći sistema Rust u novoj valjaonici Željezare Sisak. ${ }^{11}$ Na prvoj promociji koja je održana u Sisku 8. svibnja 1965. godine promovirano je 12 dipl. ing. metalurgije. Time je RH dobila prve vlastite inženjere metalurgije koji postaju nositelji metalurške i metaloprerađivačke industrije. $U$ prvih pet godina djelovanja Metalurškog odjela, tj. do kraja 1965. godine, diplomiralo je metalurgiju 26 studenata.

Problem prostora na odjelima u Sisku Tehnološkog fakulteta dolazi do izražaja krajem 60-ih godina 20. stoljeća kada se zbog izvođenja nastave na sva tri stupnja (I., II. i III.) povećava opseg predavanja i vježbi. Na temelju ugovora o suradnji (18. listopada 1969.) između Željezare Sisak, Instituta za metalurgiju i Tehnološkog fakulteta, Metalurški odjel u Sisku dobiva nove moderne prostorije $\left(620 \mathrm{~m}^{2}\right)$ osnivanjem Katedre za metalurgiju u zgradi Instituta za metalurgiju, što olakšava znanstveno-nastavne i stručne aktivnosti. Time poluindustrijska postrojenja (Greenawalt tava za sinterovanje rude željeza, eksperimentalna visoka peć itd.), laboratoriji Instituta i industrijska postrojenja u pogonima Željezare Sisak postaju dostupni za znanstveno-istraživačku i stručnu djelatnost Metalurškog odjela. Kroz izradu diplomskih radova omogućava se usmjeravanje diplomanada prema specijalizaciji za područja u kojima će kasnije dobivati zaposlenje nakon završetka studija. Time metalurška industrija istodobno dobiva rješenja pojedinačnih tehnološko-stručnih problema koja su od njezina interesa.

Za razvoj bilo kojeg znanstvenog polja, tako i polja metalurgije, veliku ulogu imaju znanstveno-istraživački rad, suradnja s gospodarstvom kao i međunarodna suradnja. Unatoč velikoj opterećenosti nastavom i skromnoj opremljenosti, već 1962. godine, istraživači s Metalurškog odjela u Sisku prijavljuju projekte koje financira Savezni fond za naučni rad. Istraživanja su se prilagođavala raspoloživim financijskim sredstvima, znanstveno-istraživačkoj opremi, a temeljila su se i na suradnji s domaćim visokoškolskim (Prirodoslovno-matematički fakultet) i znanstvenim institucijama (Institut "Ruđer Bošković", Institut za geološka istraživanja). Tako je za Savezni fond za naučni rad izrađeno niz stručnih elaborata, kao npr.: Izluživanje rude iz Vardišta (1961.), Proizvodnja feronikla iz domaćih sirovina (1961.) itd. Za potrebe UJŽ-a rađene su analize rada visokih i TH peći (1961. - 1963. 1964. - 1966.). Za potrebe Ekonomskog instituta iz Zagreba izrađen je elaborat: Perspektivni i prostorni razmještaj industrije željeza i čelika u Jugoslaviji (1966.) itd. Tijekom 1970-ih godina financiranje znanstveno-istraživačkog rada je u nadležnosti Republičkog fonda za znanstveni rad i SIZ-a za znanost. Financiraju se projekti za koje su privredna poduzeća osigurala barem 50 \% financijskih sredstava. Suradnja s gospodarstvom (Željezara Sisak, Rafinerija nafte Sisak itd.) uključivala je izradu projekata, elaborata, ekspertiza te rješavanje specifičnih problema iz područja rada pojedinih tvrtki i/ili institucija. $U$ prvih 10 godina izrađeno je više od 80 stručnih elaborata, ${ }^{8}$ a za potrebe Željezare Sisak izrađeni su elaborati: Industrijska proba topljenja ljubijskog limonita (1961.), Mikroskopsko ispitivanje sintera (1964.) itd. U povodu obilježavanja 10. obljetnice odjela u Sisku Tehnološ- kog fakulteta održan je u Sisku, od 31. ožujka do 2. travnja 1970. godine, simpozij o metalurgiji . Na simpoziju su izložena 33 rada s metalurških institucija iz Hrvatske, Slovenije, Bosne i Hercegovine te Srbije, a sažetci radova objavljeni su u časopisu Metalurgija 9 (1) (1970) 15-25.

U okviru Metalurškog odjela provodila se međunarodna suradnja, ovisno o specijalnosti nastavnika. U to vrijeme međunarodna suradnja Metalurškog odjela odvijala se putem Tehnološkog fakulteta u Zagrebu, a očitovala se sudjelovanjem djelatnika Metalurškog odjela u ekspertizama Ujedinjenih naroda (1964.) u J. Americi i Indiji, u međunarodnim stručnim timovima za specifične metalurške discipline (1965. - 1966.) itd. Na primjer, prof. V. Logomerac na osnovi znanstveno-stručnog rada 1964. godine postao je ekspertom Ujedinjenih naroda za ocjenu mogućnosti eksploatacije leteritnih ruda zemalja karipskog područja.

U prvoj generaciji u akad. god, 1967./78. na I. stupnju upisivali su se studenti na metalurškom i valjaoničarskom smjeru. Kasnije su sve generacije upisivale samo metalurški smjer. Studij je bio izvanredni dvogodišnji, a upisivali su ga uglavnom tehničari iz pojedinih tvornica (Željezara Sisak, MIV Varaždin itd.). Do 20. studenoga 1974. godine 130 studenata završilo je II. stupanj, stekavši zvanje dipl. ing. metalurgije. U razdoblju 1967. - 1974. na Metalurškom odjelu 11 studenata je završilo I. stupanj, stekavši višu stručnu spremu $(\mathrm{VI} / 1)$, odnosno zvanje inženjera metalurgije. Na poslijediplomski magistarski studij na Metalurškom odjelu upisale su se dvije generacije (1965./66. i 1970./71.). Do kraja 1974. godine obranjena su dva magisterija i tri disertacije iz znanstvenog polja metalurgije. Prvi magistar znanosti iz polja metalurgije u RH je Ilija Mamuzić, dipl. ing., koji je 5. srpnja 1971. godine obranio magistarski rad (Mogućnost primjene ultrazvuka za sondiranje odljevaka od sivog lijeva) pod mentorstvom izv. prof. dr. sc. Pavla Pavlovića. Prvi doktor znanosti iz polja metalurgije u RH postao je ing. Bhanu Prakashu, Indijac koji je bio stipendist SIV-a. ${ }^{10}$ Inženjer metalurgije B. Prakash radio je disertaciju (Proučavanje utjecaja kositra na metalurška i korozijska svojstva Fe-Si-C legura) na Metalurškom odjelu i Institutu za metalurgiju u Sisku te ju je obranio 3. ožujka 1964. godine pod mentorstvom izv. prof. Vladimira Logomerca. U okviru djelovanja Metalurškog odjela u Sisku Tehnološkog fakulteta ukupno su stečena 143 akademska zvanja i tri akademska stupnja doktora znanosti iz polja metalurgije. Stalni nastavnici i suradnici su prema bibliografskim podatcima ${ }^{12}$ u razdoblju 1960. - 1974. objavili 88 radova u domaćim (Metalurgija, Kemija u industriji itd.) i međunarodnim časopisima (Travaux de I'ICSOBA, Werkstoffe und Korrosion itd.) i 39 radova u zbornicima međunarodnih i domaćih konferencija.

\section{Metalurško inženjerstvo Tehnološkog fakulteta (1974. - 1978.)}

Preustrojem Tehnološkog fakulteta (20. studenoga 1974. godine) odjeli u Sisku reorganiziraju se u Osnovnu organizaciju udruženog rada (OOUR) Metalurško inženjerstvo, kao jedan od šest OOUR-a Tehnološkog fakulteta Sveučilišta u Zagrebu. Osnovne djelatnosti OOUR-a Metalurško inženjerstvo su znanstveno-nastavna i stručna aktivnost 
iz metalurškog inženjerstva i srodnih disciplina. $U$ to se vrijeme djelatnosti odvijaju putem šest laboratorija i dva kabineta: Laboratorij za tehničku fiziku, Laboratorij za mineralogiju sa zbirkom, Laboratorij za oplemenjivanje ruda $i$ ekstraktivnu metalurgiju, Laboratorij za teoretsku i fizičku metalurgiju, Laboratorij za ispitivanje materijala i plastičnu deformaciju metala, Laboratorij za obojenu metalurgiju, Kabinet za energetiku i metalurške peći te Kabinet za osnove društvenih nauka i strane jezike. Takva se organizacija Tehnološkog fakulteta ubrzo pokazala kao zamršena i neprikladna za učinkovit rad i poslovanje, osobito u razvoju nastavne i znanstveno-istraživačke aktivnosti.

U razdoblju 1974./75. - 1978./79., nakon dvije zajedničke godine, uvedena su dva smjera na studiju metalurgije: crna i obojena metalurgija. Pri tome su ukinuti neki postojeći, a uvedeni novi predmeti: Teorija metalurških procesa, Teorija i tehnologija plastične deformacije, Metalurgija zavarivanja, Korozija i zaštita, Prerada obojenih metala itd. Znanstvena aktivnost usmjerena je na obogaćivanje mineralnih sirovina, industrijsko taljenje crvenog mulja u elektro peći ljevaonice Željezare Sisak s ciljem dobivanja sirovog željeza. Iz nastale troske izlučivanjem su dobiveni: V, Cr, Ti, Nb i Ce. Od 1976. godine znanstveno-istraživačka aktivnost odvija se i u okviru projekta: Sirovine, materijali i proizvodni procesi, odnosno potprojekta Metalurgija. Rezultati istraživanja objavljeni su u 17 znanstvenih i stručnih radova u časopisima (Metalurgija, Kemija $u$ industriji, Nafta, Travaux de I'ICSOBA itd.), 20 radova je objavljeno u zbornicima konferencija (zbornici radova jugoslavenskog simpozija o pripremi mineralnih sirovina, oktobarskog savjetovanja rudara i metalurga, JUREMA, Int. Cong. of ICSOBA itd.) te je izrađeno 18 stručnih elaborata (Željezara Sisak, INA-Rafinerija nafte Sisak, Republički fond za znanstveni rad itd.) i brojni stručni izvještaji. Neki od radova objavljenih u časopisima su: Peć s pokretnom podnicom za zagrijavanje gredica (1975.), Rasprostiranje temperature u sloju mješavine za vrijeme procesa sinteriranja (1976.), Matematički modeli procesa u trupu visoke peći (1977.) itd. Izrađeni su stručni elaborati za SIZ znanosti: Mogućnost kvantitativnog opisivanja i praćenja metalurških procesa (1975.), Kvantitativno opisivanje visokopećnog procesa (1978.) itd., za Željezaru Sisak: Mineralni sastav i struktura livnih praškova (1975.), Završna ispitivanja livnih praškova $i$ izrada internih propisa za ocjenu njihove kvalitete (1978.) itd., a za potrebe INA-Rafinerije nafte Sisak izrađen je elaborat: Izdvajanje metala procesom kalcinacije petrol koksa u temperaturnom području od 1200 do $2000{ }^{\circ} \mathrm{C}$ (1976.) itd.

U razdoblju od 1974. do 1978. godine 71 student završio je II. stupanj, stekavši zvanje dipl. ing. metalurgije, a 25 studenata steklo je zvanje inženjera metalurgije. Na poslijediplomski magistarski studij na Metalurškom inženjerstvu upisala se jedna generacija (1976./77.) od 24 studenta. Izmijenjen je nastavni plan i program diplomskog studija metalurgije s naglaskom na predmete iz plastične deformacije: Teorija i praksa plastične deformacije, Fizikalno-metalurški osnovi plastične deformacije. U razdoblju 1974. - 1978. obranjeno je 12 magisterija i četiri disertacije iz znanstvenog polja metalurgije. U okviru djelovanja OOUR-a Metalurško inženjerstvo u Sisku Tehnološkog fakulteta Sveučilišta u Zagrebu ukupno je stečeno 108 akademskih zvanja i 4 akademska stupnja doktora znanosti iz polja metalurgije.

\section{Institut za lake metale u Zagrebu (1949. - 1968.)}

Institut za lake metale (ILAM) u Zagrebu bavio se istraživanjem obojenih metala (primarno aluminij i aluminijske legure), uključujući njihovo lijevanje, koroziju i zaštitu, zavarivanje, lemljenje i lijepljenje itd. ILAM je osnovan 1949. godine kao istraživačko-znanstvena institucija i djelovao je do 1968. godine. Prof. Niko Malešević (istaknuti stručnjak iz ljevarstva i znanosti o metalnim materijalima i dugogodišnji profesor na FSB-u u Zagrebu) bio je voditelj na početku rada Instituta za lake metale. Institut je imao laboratorijsku ljevaonicu za lijevanje aluminija i njegovih legura, kemijski i mehanički laboratorij itd. Od značajnije opreme mogu se izdvojiti uređaj za rendgenska ispitivanja, uređaje za zavarivanje itd. U tom kontekstu znanstveni istraživači ILAM-a objavili su u časopisu Ljevarstvo rad: Aluminijska ljevačka slitina visokih mehaničkih svojstava (1961.), a u časopisu Zavarivanje objavljeni su radovi: Izvori poroziteta pri zavarivanju lakih metala (1960.), Berilij i titan u varovima AlMg5 legura (1961.), Poboljšanje kvaliteta vara mehaničkim i ultrazvučnim vibracijama, te zavarivanje ultrazvukom i elektronskim bombardiranjem (1963.) itd. Kao rezultat istraživanja izrađeno je 10-ak industrijskih elaborata za potrebe TLM-a Šibenik od kojih se mogu izdvojiti: Zaštita poluproizvoda iz aluminijskih legura kod skladištenja $i$ transporta (1965.), Poboljšanje tehnologije izrade valjanih poluproizvoda iz legura AlMg3, AlMg4 i AlMg5 (1966.), Poboljšanje tehnologije izrade hipereutektičke AlSi ljevačke legure L-63 (1968.) itd.

\section{Institut za metalurgiju u Sisku MK Željezara Sisak (1961. - 1978.)}

Institut za metalurgiju u Sisku osnovan je 3. veljače 1961. godine. Osnivač Instituta je Željezara Sisak, a suosnivač Tehnološki fakultet Sveučilišta u Zagrebu. ${ }^{13}$ Najaktivniji u osnivanju Instituta i prvi njegov direktor bio je izv. prof. Vladimir Logomerac. Institut je 31. prosinca 1961. godine imao ukupno zaposlena 222 djelatnika od kojih je bilo 13 inženjera. Zgrada Instituta je fizički locirana u krugu Željezare Sisak (slika 2). Institut je izrastao izravno iz Željezare Sisak iz dotadašnjeg Sektora za istraživanje (osnovanog 1957. godine). Već pri osnivanju Institut je zamišljen kao znanstvena institucija usmjerena na primijenjena (posebice prema potrebama Željezare Sisak), a dijelom na fundamentalna istraživanja, kao i na usluge prema drugim znanstvenim, visokoškolskim i gospodarskim institucijama te republičkim i saveznim udruženjima (suradnja u okviru UJŽ-a preko Odbora za znanstvenoistraživački rad na problemima od interesa za sve jugoslavenske željezare itd.). Tek osnivanjem Instituta organizirani znanstveno-istraživački rad u polju metalurgije dobiva zamah jer se ostvaruje zamisao suradnje znanosti, istraživanja i neposredne proizvodnje. Time započinje još bolja suradnja Metalurškog odjela u Sisku i realnog metalurškog gospodarskog sektora. Provodila su se i istraživanja primjene crvenog mulja kao sirovine za izradu sirovog željeza uz iskorištavanje korisnih primjesa u crvenom mulju, što je objavljeno u elaboratu: Studija uslova i načina prerade crvenog mulja (1962.). Institut posredstvom SIZ-a za znanost koordinira 
znanstveno-istraživački rad iz polja metalurgije SR Hrvatske, surađujući s ostalim institutima. Prvih godina Institut se "uhodavao" u radu, pojavili su se problemi s kadrovima (posebno s visokostručnim), nedostatkom znanstenoistraživačke opreme, ali i nedostatkom prostora.

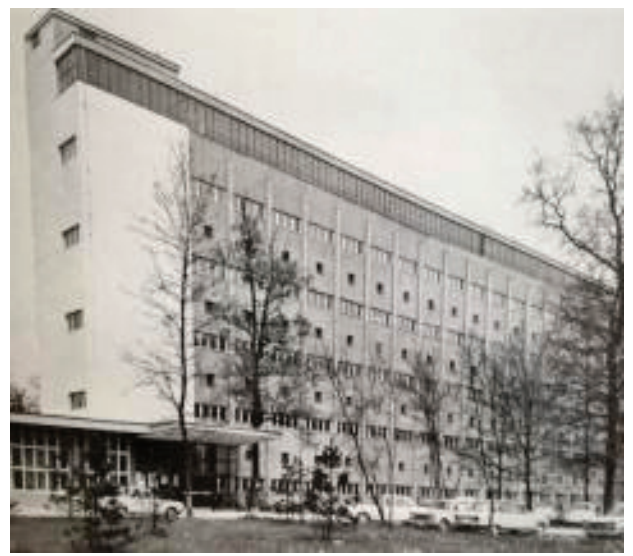

Slika 2 - Glavna zgrada Instituta za metalurgiju u Sisku (1970.-ih) Fig. 2 - Main building of the Sisak Institute for Metallurgy (1970s)

U prvom razdoblju rada (koje traje do kraja 1964. godine) Institut se uglavnom bavio istraživanjem sirovinske baze crne metalurgije bivše Jugoslavije. Institut je u prvih pet godina djelovanja imao šest organizacijskih cjelina, od kojih su za razvoj polja metalurgije bile najvažnije dvije cjeline: Laboratoriji i Poluindustrijski uređaji. ${ }^{14}$ Laboratoriji su uključivali općekemijski laboratorij (kvalitativna i kvantitativna spektroskopija metala, kalorimetrijska analiza itd.), fizikalno-kemijski laboratorij (određivanje plinova, DTA analiza i analiza reduktivnosti, antikorozijska zaštita itd.), fizikalni laboratoriji (mehanički, metalografski, defektoskopski itd.). Institut za metalurgiju Sisak bio je jedan od najbolje opremljenih instituta crne metalurgije u bivšoj Jugoslaviji s poluindustrijskim uređajima koji su upotrebljavani za ostvarivanje uvjeta bliskih realnom praktičnom metalurškom pogonu. Poluindustrijski uređaji bili su raspoređeni u okviru četiriju odjela: Odjel za metalurško oplemenjivanje i taljenje ruda željeza (rotacijske peći za magnetizirajuće prženje i za direktnu redukciju, pokusna visoka peć, Greenawalt tava za sinteriranje rude, tanjuri za peletiziranje rude, magnetski separatori itd.), Odjel za čelik i legure (visokofrekventne indukcijske peći s odgovarajućim loncima za taljenje uloška, indukcijska vakuumska peć za taljenje i lijevanje metala i legura, elektrootporne peći za toplinsku obradu itd.), Odjel za galvanizaciju (uređaji s kadama i kupkama za galvansko nanošenja prevlaka: niklovanje, pocinčavanje, dekorativno kromiranje, tvrdo kromiranje itd.), Odjel za hidrometalurgiju (uređaj za izluživanje, za vakuumsku filtraciju itd.).

Istraživanja Instituta usmjerena su na pripremu i metalurško oplemenjivanje ruda željeza iz Bešlinca i Ljubije, istraživanje domaćih ugljena (naročito kamenih) i petrolkoksa za djelomičnu primjenu u procesu proizvodnje sirovog željeza, intenzifikaciju tehnoloških procesa proizvodnje sirovog željeza, čelika, valjanih proizvoda, čeličnog i sivog lijeva, proučavanje procesa hidrometalurgije za ekstrakciju metala (Ni, Ci i Mn), usvajanje novih kvaliteta s ciljem proširivanja proizvodnog asortimana proizvodnje cijevi (npr., hladnog vučenja, pocinčavanja i antikorozijske zaštite cijevi itd.), istraživanje u proizvodnji prešanih magneta, istraživanje u okviru ispitivanja metala (mehanička, tehnološka, metalografska, ispitivanja metodama bez razaranja itd.), istraživanje iz analitičke kemije (analiza rudnih sirovina, sirovog željeza, čelika, troske, gotovih proizvoda, zagađenosti atmosfere u pogonima itd.), istraživanje faznog sastava primjenom rendgenske analize, pripremu i izradu standarda u analitičkoj kemiji itd.

U drugom razdoblju rada Instituta (od 1. siječnja 1965. godine, kad su tzv. pogonski laboratoriji Željezare Sisak integrirani s Institutom) znanstveno-istraživačke i stručne aktivnosti primarno su usmjerene na problematiku Željezare Sisak. Godine 1965. Institut je imao 172 zaposlenika, a za potrebe Željezare Sisak radilo se na 25 zadataka. ${ }^{5}$ Neki od istraživačkih zadataka su: Povećanje kalorične vrijednosti visokopećnog plina za aglomeraciju, Antikorozijska zaštita finalnih proizvoda MK Zeljezare Sisak kod uskladištenja i transporta, Definiranje optimalnih uvjeta termičke obrade čeličnih boca itd. Ostali znanstveno-istraživački rad financiran je iz Fondova za naučni rad. Od 1965. godine prestrukturirali su se postojeći i ustrojavali novi pojedini laboratoriji (laboratorij za analitičku i fizikalnu kemiju, ispitivanje materijala s razaranjem i bez razaranja, metalografiju i fizičku metalurgiju), a osnivaju se i novi odjeli. Institut je od 1967. godine djelovao kao radna jedinica, a od 1 . siječnja 1973. godine djeluje kao OOUR Institut za metalurgiju (196 zaposlenika) s vlastitim računom i pravnom subjektivnošću u okviru Željezare Sisak (1973. - 1978.). Nova zgrada Instituta (slika 2) dovršena je 1968. godine od kada postupno dolazi i do opremanja laboratorija i odjela s novijom opremom: kemijski, metalografski, laboratorij za DTA i TGA analizu, laboratorij za ispitivanje faza u čeliku, laboratorij za ispitivanje plinova u čeliku, laboratorij za ispitivanje bez razaranja, odjel za plastičnu preradu itd. Istraživački rad sve se više odnosi na proizvodne pogone Željezare Sisak s primarnim usmjerenjem prema intenziviranju postojećih kapaciteta, usavršavanju i finalizaciji proizvodnje itd. Sklapanjem ugovora (18. listopada 1969.) o međusobnoj suradnji (Željezara Sisak - Institut - Tehnološki fakultet) Institut preuzima ulogu povezivanja znanosti i gospodarstva. Time su stvorene pretpostavke za investiranje u noviju opremu, bolju zajedničku koordinaciju i ostvarivanje dugoročnijih planiranja aktivnosti, boljeg usmjeravanja i doškolovanja kadrova.

Odjeli su usmjereni na problematiku Željezare Sisak, kao npr. odjeli za pripremu i preradu željeza, proizvodnju čelika, plastičnu preradu čelika, finalizaciju i antikorozijsku zaštitu, primjenu plastike u metalurgiji te Odjel za zavarivanje konstrukcija iz čeličnih cijevi i testiranje zavarivača. Navedene organizacijske jedinice smještene su na $35807 \mathrm{~m}^{2}$ radne površine u krugu Instituta za metalurgiju Željezare Sisak u više zgrada. U prizemlju zgrade Instituta nalazila se i Katedra za metalurgiju Metalurškog odjela, koja surađujući s Institutom nastavlja upotrebljavati laboratorijske i poluindustrijske uređaje za znanstveno-nastavni rad. Institut je imao dobro ekipiranu i opremljenu službu strojnog i elektro održavanja, odgovarajuće opremljenu radionicu za pripremu uzoraka koje su bile u stanju projekti- 
rati i samostalno izraditi pomoćnu znanstveno-istraživačku opremu. U Institutu je, kao rezultat suradnje s odjelima Tehnološkog fakulteta u Sisku, u prvih 10 godina izrađeno više od 100 diplomskih radova, tri doktorske disertacije, četiri magistarske radnje, više od 250 znanstvenoistraživačkih studija i elaborata, 25 tehničko-proizvodnih rješenja iz polja metalurgije. ${ }^{14}$ Od navedenih 25 korisnih stručnih rješenja za Željezaru Sisak mogu se izdvojiti: Zamjena sitnog koksa kod sinteriranja s poluantracitom i petrolkoksom, Proizvodnja cijevi N-80 za naftnu industriju iz čelika s niskim dodacima vanadija, Uvođenje poligonalnih ingota $u$ valjaonici bešavnih cijevi itd.

Treće razdoblje rada Instituta počinje od 1970. godine kad se donose dugoročniji planski programi istraživanja temeljeni na samostalnijem znanstveno-istraživačkom radu, nabavi novije opreme (slika 3) i na podizanju kadrovske strukture. Institut je ostvarivao prihode od uslužnog i znanstveno-istraživačkog rada, s tendencijom da se što veći prihod ostvari od znanstveno-istraživačkog rada. Na primjer, u 1971. godini je ostvarivao oko $60 \%$ prihoda od uslužnog, a oko 40 \% od znanstveno-istraživačkog rada. Dužna se pažnja u Institutu poklanjala dodatnom cjeloživotnom obrazovanju i usavršavanju zaposlenika. Institut je stipendirao inženjere (posebno metalurge), tako je do kraja 1971. godine imao 40 inženjera od ukupno 180 zaposlenika. Željezara Sisak ulaže znatna sredstva u nabavu nove znanstveno-istraživačke opreme. Za brzu analizu taline čelika za vrijeme njezine izrade uspostavljena je tzv. "zračna pošta" između pogona čeličane i kemijskog laboratorija u podrumskom dijelu zgrade Instituta. Uzorci ohlađene taline čelika iz čeličane dostavljani su putem tzv. "brze pošte" u čahuri (kao u metku). Nakon pripreme uzorci su analizirani na tzv. kvantometru, metodom emisijske spektralne analize. S obzirom na to da je to bila brza analiza koja se provodila u trosmjenskom neprekidnom radu (5 -7 minuta), na osnovi dobivenih rezultata $u$ kratkom vremenu mogla se provoditi eventualna korekcija kemijskog sastava taline u tehnološkom procesu dobivanja čelika i odljevaka. Institut za metalurgiju nabavio je (sredstvima Željezare Sisak i uz pomoć Republičkog savjeta za obrazovanje, znanost i kulturu) 17. kolovoza 1976. godine prvi pretražni elektronski mikroskop (SEM) s valno disperzijskim spektrometrom (WDS) za kvantitativnu elektronsku mikroanalizu (JEOL JXA 50A) u RH. ${ }^{15}$ SEM se upotrebljavao za znanstveno-istraživački rad, primarno za analizu tehnoloških problema Željezare Sisak (slika 4), kao npr. analiza bešavnih i šavnih cijevi, difuzijskih i korozijskih mehanizama, nemetalnih uključaka itd. Također se upotrebljavao i za izradu stručnih elaborata, studija, ekspertiza i stručnih izvještaja (za gospodarske subjekte grada Siska, današnje Sisačko-moslavačke županije i RH, ali i šire) s ciljem utvrđivanja uzroka oštećenja ili lomova metalnih proizvoda (npr. mikroanaliza turbinskih lopatica, lopatica ventilatora, cijevi za namjensku industriju, analiza lebdećih prašina nad gradom Siskom itd.), izradu diplomskih, magistarskih i doktorskih radova, edukacije studenata metalurgije iz predmeta Fizička metalurgija. ${ }^{16}$ Institut je prvi u bivšoj Jugoslaviji prešao s ručnog računanja na primjenu računala za mikroanalizu uzimajući u obzir faktore korekcija na atomski broj, na apsorpciju i na fluorescenciju za svaki analizirani element. Obradom podataka pomoću računalnog programa FORTRAN V u elektronskom računalnom centru Željezare
Sisak s računalom treće generacije UNIVAC 1106 (1972.), jednim od najvećih u bivšoj Jugoslaviji, dobivala se precizna kvantitativna analiza čelika i ostalih materijala. ${ }^{16}$

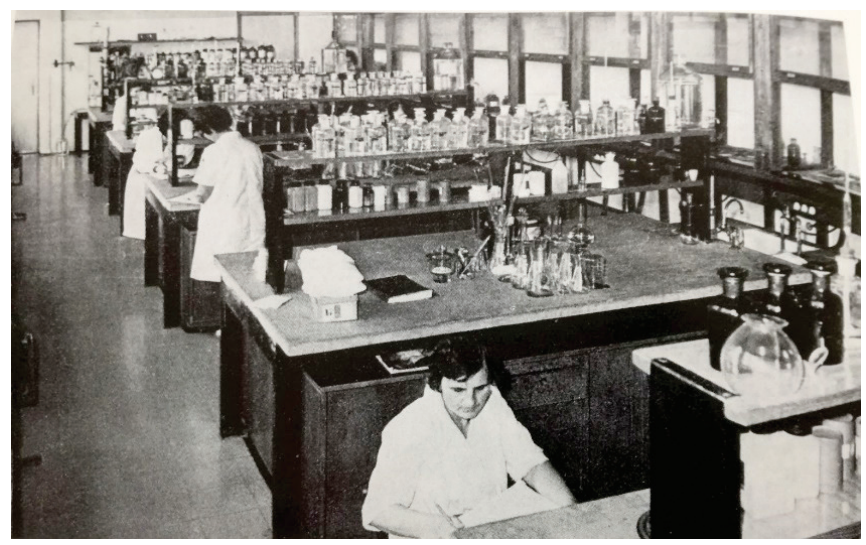

Slika 3 - Kemijski laboratorij Instituta za metalurgiju u Sisku (1970.-ih)

Fig. 3 - Chemical laboratory of the Sisak Institute for Metallurgy (1970s)

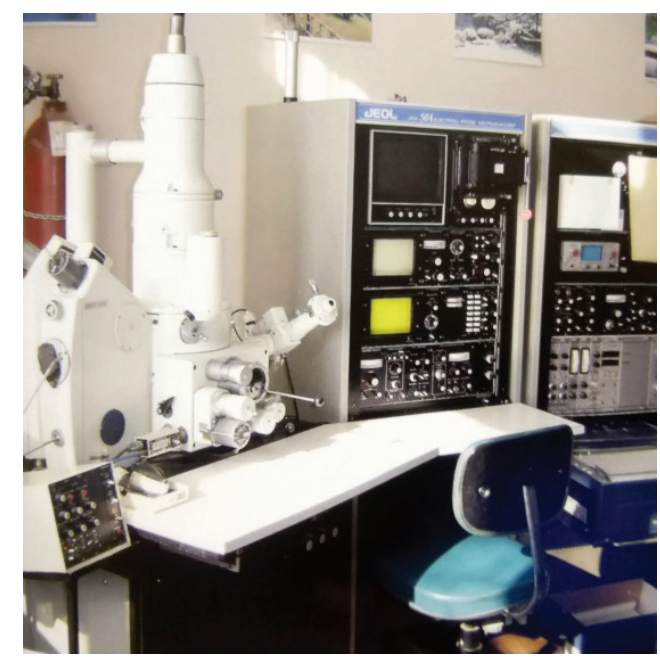

Slika 4 - Pretražni elektronski mikroskop (SEM JEOL JXA 50 A) s valno disperzijskim spektrometrom (WDS) Instituta za metalurgiju (od 2002. je na Metalurškom fakultetu u Sisku)

Fig. 4 - Scanning electron microscopy (SEM JEOL JXA 50 A) with wavelength dispersive spectroscopy (WDS) of the Institute for Metallurgy (since 2002, the SEM is located at the Sisak Faculty of Metallurgy)

Za potrebe utvrđivanja svojstava plastičnosti i deformacijskog otpora metalnih materijala nabavljen je (za Odjel za plastičnu preradu) torzioni plastometar francuskog proizvođača Adamel Lhomergy (prvi uređaj takve vrste u bivšoj Jugoslaviji), uređaj za vlačna ispitivanja pri sobnoj i pri povišenim temperaturama (Zwick $50 \mathrm{kN}$ ), za potrebe toplinske analize nabavljena je oprema TGA, DTA i horizontalni dilatometar (tvrtke Netzsch) te ultra-brzohladeći vertikalni 
dilatometar LK 02 (Adamel Lhomergy), za analizu plinova u čeliku nabavljen je analizator plinova (kisik, dušik i vodik) Exhalograph EA1 tvrke Balzers AG, emisijsko spektrometrijski kvantometar 31000 ARL za određivanje kemijskog sastava metalnih materijala, atomski apsorpcijski spektrometar (AAS) Perkin Elmer 503 itd.

Institut je mogao provoditi: lijevanje u kokile (čelik, lijevana željeza, aluminij i njegove legure itd.), toplinsku obradu, mehanička i tehnološka ispitivanja, brojne analize: kemijskog sastava, konstitucijskih faza i plinova u metalnim materijalima, metalografska analiza (svjetlosna i pretražna elektronska mikroskopija), toplinsku analizu (termogravimetrija, dilatometrija, diferencijalno toplinska analiza), rendgensku fluorescentnu i difrakcijsku analizu, ispitivanje materijala metodama bez razaranja (ultrazvuk, penetranti itd.), određivanje svojstava plastičnosti i deformacijskog otpora, analizu metodom atomske apsorpcijske spektrometrije itd. Na osnovi vlastitih istraživanja Institut je usvojio postupak galvanskog pocinčavanja spojnica cijevi za naftnu industriju, katodnu zaštitu plinskih i vodovodnih cijevi, uveo je tzv. mini-proizvodnju domaćeg sredstva za smanjenje koeficijenta trenja pri hladnom vučenju čeličnih cijevi itd. Provodio je atestiranje zavarivača različitim postupcima zavarivanja, ispitivanja materijala metodama bez razaranja (NDT metode), organizirao i održavao edukaciju za rad NDT metodama na razini Željezare Sisak, šire regije, kao i na razini bivše Jugoslavije (posebno za NDT ispitivanje zavarenih spojeva, odljevaka itd.), sudjelovao u izradi prijedloga standarda za kemijska ispitivanja itd.

Institut je imao odličnu međunarodnu (od 1964.) i domaću suradnju. Posebno je dobro surađivao s Rudarskim akademijama u Freibergu i Aachenu (Njemačka), što se manifestiralo u sudjelovanju na stručnim specijalizacijama i usavršavanju, studijskim boravcima, organiziranju tzv. "kontakt studija" (u razdoblju 1974. - 1978. tri tzv. "kontakt studija" s Visokom tehničkom školom iz Aachena i s Rudarskom akademijom iz Freiberga) koji su namijenjeni prenošenju novostečenih saznanja stručnjacima u neposrednoj metalurškoj proizvodnji itd. Institut je surađivao sa Stahlinstitut Hennigsdorf, Forschungsinstitut Mannesmann (Njemačka), Mađarskim udruženjem metalurga, sa zemljama SEV-a i EEZ-a u okviru međunarodnih istraživačkih projekata. U Institutu je održano niz međunarodnih kolokvija i simpozija na pojedinim temama iz metalurgije (Oprema $i$ postrojenja valjaonica - 1970., Odredivanje plinova u metalima - 1972. itd.). Treba izdvojiti međunarodni kolokvij "Uložak za bešavne cijevi" održan u Sisku (7. - 10. svibnja 1970.), gdje je predstavljeno ukupno 20 radova (sedam iz Željezare Sisak i Instituta za metalurgiju, a 13 iz inozemstva: Njemačka, Italija, Mađarska i Cehoslovačka), koji su objavljeni u posebnom broju časopisa Metalurgija u 1970. godini. Također je imao izvrsnu suradnju s metalurškim institutima iz bivše Jugoslavije (Ljubljana, Zenica, Bor itd.), bilateralnu suradnju sa znanstvenim institucijama (Institut "Ruđer Bošković" itd.), Tehnološkim fakultetom u znanstveno-istraživačkom i stručnom radu, razmjeni literature i informacija itd. Posredstvom Odbora za znanstvenoistraživački rad UJŽ-a, Institut surađuje na istraživačkim zadatcima relevantnim za sve jugoslavenske željezare, posredstvom SIZ-a za znanost koordinira znanstveno-istraživački rad na polju metalurgije SR Hrvatske, surađujući s ostalim institutima iste zajednice. Također je dobro surađivao sa stručnim društvima, kao npr. Društvo inženjera Sisak, Društvo inženjera i tehničara (DIT) Željezare Sisak, Društvo za tehniku zavarivanja (DIT) itd. Institut je 15. siječnja 1977. godine registriran pri Republičkom savjetu za naučni rad kao znanstvena organizacija, što je osiguralo da se natječe za znanstveno-stručne projekte na saveznoj i republičkoj razini. U to je vrijeme Institut imao 201 zaposlenika u stalnom radnom odnosu, od kojih je 50 s visokom stručnom spremom, pet doktora i deset magistara znanosti u polju metalurgije. Prema bibliografskim podatcima ${ }^{12}$ rezultati ukupnih aktivnosti Instituta za razdoblje 1961. - 1978. u okviru šest metalurških segmenata (1 - Koks, ruda, gvožđe, 2 - Čelik i ljevarstvo, 3 - Prerada metala i površinska obrada, 4 -Materijali, 5 - Energetika u metalurgiji i 6 - Kemija i kemijska tehnologija) objavljeni su u 136 znanstvenih i stručnih radova u domaćim časopisima (primarno u časopisu Metalurgija - 91 rad, ali i u drugim domaćim časopisima: Kemija u industriji, Strojarstvo, Nafta, Zavarivanje, itd.) i u međunarodnim časopisima (Neue Hütte, Travaux de I'ICSOBA itd.), 68 radova objavljeno je u zbornicima konferencija, te je izrađen 441 stručni elaborat (Željezara Sisak, Savezni fond za naučni rad, UJŽ, SIZ znanosti SR Hrvatske itd.), oko 160 studija, stručnih izvještaja i ekspertiza. Najveći "pečat" u razvoju Instituta za metalurgiju ostavio je dugogodišnji direktor (1964. - 1980.) prof. dr. sc. Pavle Pavlović, dr. h. c., vanjski suradnik (1963. - 1980., 1985. - 1987.) i nastavnik na današnjem Metalurškom fakultetu (1980. - 1985.), glavni urednik (1965. - 1966.) te glavni i odgovorni urednik (1967. - 1982.) časopisa Metalurgija. Prof. P. Pavlović uspio je podići razinu Instituta za metalurgiju od industrijskog instituta do znanstvene organizacije (krajem 1970-ih godina) u RH. Pored toga, bio je mentor najvećem broju studenata (101) u RH za stjecanje akademskog zvanja u polju metalurgije (13,2 \% od ukupno stečenih akademskih zvanja do 2019.) na Metalurškom odjelu i Kemijskom inženjerstvu Tehnološkog fakulteta kao i na Metalurškom fakultetu (6 - doktora znanosti, 12 - magistara znanosti, 73 - dipl. ing. met. i 10 - ing. met.).

\section{Metalurški fakultet u okviru Željezare Sisak (1979. - 1991.)}

Integracijom (1. siječnja 1979. godine) OOUR-a Metalurško inženjerstvo Tehnološkog fakulteta i OOUR-a Institut za metalurgiju nastaje Radna organizacija (RO) Institut za metalurgiju (271 zaposlenika) u okviru Složene organizacije udruženog rada (SOUR) Željezare Sisak. Novonastala RO objedinjuje znanstveno-istraživački rad s obrazovnim procesima i bila je jedna od najvećih u bivšoj Jugoslaviji u polju metalurgije. RO Institut za metalurgiju sastoji se od dva OOUR-a: Metalurški fakultet (104 zaposlenika) i Tehničko uslužna djelatnost (TUD, 108 zaposlenika) te Radne zajednice (59 zaposlenika).9,17 Metalurški fakultet 1 . veljače 1979. godine postaje jedna od, u to vrijeme, 56 sastavnica Sveučilišta u Zagrebu. Vodeću ulogu u znanstveno-istraživačkoj djelatnosti u Institutu preuzima OOUR Metalurški fakultet, dok je OOUR TUD primarno usmjeren na ispitivanja prema proizvodnim pogonima Željezare Sisak kao i prema pružanju stručnih usluga drugim zainteresiranim korisnicima (klasična "rutinska" ispitivanja: mehanička, kemijska, metalografska itd.), provođenje osposobljavanja ka- 
drova za zavarivače, uz izdavanje odgovarajućih atesta itd.

Navedena integracija u Željezaru Sisak bila je od velikog značenja i za znanstveno-istraživačku i stručnu djelatnost Metalurškog fakulteta, jer je Institut imao funkcionalne temeljne laboratorije i poluindustrijske uređaje. Pri tome dolazi i do otvaranja novih istraživačkih područja u polju metalurgije (istraživanje serpentinita, ravnotežnih dijagrama stanja itd.). Povećani su izvori financiranja od prodaje karburita (sredstvo za naugljičenje taline) i bondera (sredstvo za premazivanje cijevi prije hladnog vučenja) za pogon Hladne prerade Željezare Sisak itd. Teme diplomskih radova većinom su bile u okviru problematike za potrebe Željezare Sisak, što je danas gotovo nezamislivo. To je "zlatno doba" Metalurškog fakulteta jer su stvorene pretpostavke za podizanje razine nastavne aktivnosti (posebice u izvođenju vježbi), za interdisciplinarnu suradnju koju je već Institut imao, kao i za brži transfer znanja i znanstvenih dostignuća u realni sektor gospodarstva, što je i danas aktualno..$^{18}$ Tom se integracijom znatno poboljšala kadrovska struktura Metalurškog fakulteta (56 djelatnika radi u nastavi kao znanstveno-nastavno i nastavno osoblje uz 14 doktora tehničkih znanosti, od kojih je šest iz polja metalurgije), a djelatnost Metalurškog fakulteta odvija se putem pet zavoda i jedne katedre: Zavod za kemiju, Zavod za fizičku metalurgiju i materijale, Zavod za metalurgiju gvožđa, čelika i ljevarstvo, Zavod za energetiku, plastičnu preradu metala i strojarstvo, Zavod za metalurgiju obojenih metala te Katedre za opće programske osnove. Kasnije se ta organizacija promijenila i aktivnosti su se odvijale u četiri zavoda: Zavod za kemiju i obojenu metalurgiju, Zavod za fizičku metalurgiju i materijale, Zavod za metalurgiju, Zavod za preradu i površinsku obradu metala, energetiku i strojarstvo.

Ponovno se (od 1978./79.) uvodi četverogodišnji studij metalurgije s dva smjera (prerada metala i procesna metalurgija), ali su zajedničke prve dvije godine studija. Pored nastave metalurgije za stjecanje akademskog zvanja diplomiranog inženjera metalurgije, povremeno se provodi nastava za stjecanje zvanja inženjer metalurgije kao i nastava na poslijediplomskom magistarskom studiju metalurgije. Dio tema diplomskih i magistarskih radova u okviru je istraživačkih projekata. Od akad. god. 1981./82. usvaja se novi nastavni plan i program četverogodišnjeg studija metalurgije općeg smjera. Pri tome se uvode i novi predmeti kao npr. Automatizacija i vođenje procesa, Zaštita okoline, Znanstvena informatika itd. U VIII. semestru nudi se mogućnost izbornih predmeta: Proizvodnja cijevi, Hidrometalurgija, Prerada obojenih metala, Programiranje itd.

$U$ to vrijeme znanstvena se aktivnost Metalurškog fakulteta odvijala kroz znanstvene projekte koje financiraju savezne (UJŽ, OUCMJ, Savezni fond za poticanje tehnološkog razvoja) i republičke institucije (SIZ znanosti, Republička zajednica za znanstveni rad), Fond za znanstveno-istraživački rad Željezare Sisak itd. Savezni fond za poticanje tehnološkog razvoja financirao je projekt (1988. - 1989.): Plazma tehnologija za obradu površine materijala. U okviru Zavoda za metalurgiju gvožđa, čelika i ljevarstvo mnogo se istraživalo u području primjene livnog praha preko prioritetnog istraživačkog projekta: Uvođenje domaćih livnih praškova za kontinuirano lijevanje (1983. - 1984.), koji je financirala Republička zajednica za znanstveni rad SR Hrvatske. U suradnji s ljevaonicom Željezare Sisak za potrebe domaće industrije usvojena je proizvodnja visokolegiranih čeličnih ljevova i visokosilicijeva željeznog lijeva za izradu centrifugalnih kiselootpornih pumpi (1987. - 1988.). Izrađene su i analize utroška materijala i energenata po pojedinim proizvodnim pogonima Željezare Sisak u okviru međurepubličkog dugoročnog (1986. - 1990.) projekta: Razvoj strojarskih i metalurških proizvoda i postupaka proizvodnje tvorevina u konceptu njihove računalom integrirane proizvodnje. Znanstveno-istraživački rad na razini Željezare Sisak odvijao se u okviru projekata: Metalurgija željeza $i$ čelika, Svojstva i prerada materijala, Separacija i analiza metala te Energetika, toplotehnika $i$ vatrostalni materijali. Neki od zadataka su: Izrada atlasa grešaka na bešavnim cijevima (1979.), Optimalizacija zagrijavanja cijevi u Selas pećima (1981.), Zamjena kokila iz sivog lijeva (1983.), Poboljšanje lijevanja blumova osmerokutnog presjeka (1985.), Separacija elemenata rijetkih zemalja (1987.) itd. S obzirom na to da je Željezara Sisak bila jedini proizvođač bešavnih cijevi u bivšoj Jugoslaviji, radilo se i na tzv. selektivnom programu: Razvoj bešavnih cijevi za istraživanje i proizvodnju nafte i plina u posebno teškim uvjetima i u podmorju. Za koksaru Bakar istraživana je raspodjela sumpora u ugljenu i produktima pri proizvodnji koksa te mogućnost prerade i upotrebe nusproizvoda iz koksnog plina. Ispitivan je utjecaj petrografskog sastava različitih ugljena u mješavini s ciljem optimalizacije procesa i dobivanja kvalitetnog koksa. ${ }^{19} \mathrm{U}$ tehnologiji proizvodnje čelika postignuta je veća čistoća sirovog čelika (obrada žicom punjenom kalcij-silicijem s ciljem modifikacije nemetalnih uključaka), bolja homogenost taline (uvođenjem argona) te veća kvaliteta površine kontinuirano lijevanih poluproizvoda, povećanje izvatka (1986. - 1990.) itd.

Zbog nedostatka odgovarajuće skupe opreme razvijene su vlastite suvremene metoda ispitivanja i izradili nužni uređaji. Uvedene su metode mjerenja toplinske vodljivosti i viskoznosti rastaljenih prahova kao i temperaturnog polja koje se uspostavlja u međusloju rastaljeni/nerastaljeni prah, izrađena je peć za toplinsku vodljivost praškastih materijala, kalorimetar za određivanje gustoće toka kroz sloj praha, uređaj za mjerenje brzine taljenja praha itd.

Zapaženi su rezultati postignuti pri proizvodnji toplovaljanih traka, šavnih i bešavnih cijevi te tehnologiji hladnog pilgerovanja čeličnih cijevi i optimizaciji programa hladnog vučenja cijevi, proizvodnji konstrukcijskih čelika s granicom razvlačenja iznad $600 \mathrm{MPa}$, proizvodnji čeličnog lijeva u elektrolučnoj peći itd. Radilo se na rješavanju površinske pripreme cijevi kod hladne prerade, antikorozijskoj zaštiti konstrukcija, proizvodnji visokolegiranog čeličnog lijeva itd.

Veliko značenje za grad Sisak i širu regiju imali su i projekti iz područja zaštite okoliša: Stanje nadzora i potrebe nadzora čovjekove okoline u Sisku (1981.), Program dugoročnog nadzora i zaštite okoliša u općini Sisak (1982. - 1983.) i Studija o opterećenju gradskog područja Siska zagađujućim industrijskim tvarima (1985.). Tijekom tih projekata se osim ostalog sustavno istražuju, prate i kontroliraju zagađivači zraka, tla i vode, valorizira problematika pitke vode te kontinuiranog i kvalitetnog rješavanja komunalnog otpada. $U$ to vrijeme djelovanja intenzivira se i stručna suradnja i s drugim gospodarskim subjektima u RH i bivšoj 
Jugoslaviji, kao što su Rafinerija nafte Sisak, Aluminijski kombinat Mostar, TLM Šibenik itd. Za Rafineriju nafte Sisak istraživana je raspodjela i sadržaj metala u frakcijama nafte te utjecaj i moguće izdvajanje sumpora. Razrađen je novi način pripreme uzoraka za analizu metala u tragovima $(\mathrm{V}, \mathrm{Fe}, \mathrm{Ni}$, Sb). Za tvornicu anoda u Mostaru istraživan je utjecaj sirovina, a posebno utjecaj S, V i Na u komponentama anodne mase na kvalitetu ugljičnih anoda itd. U publicističkom smislu najviše objavljenih radova je iz područja proizvodnje i lijevanja čelika, energetike i plastične deformacije materijala te iz metoda analize (SEM, XRD, XRF itd.). Zaposlenici tih laboratorija su sa svojim objavljenim radovima u časopisima te na međunarodnim i domaćim konferencijama bili među vodećim u bivšoj Jugoslaviji.

Uspostavljena je i nova međunarodna znanstveno-tehnička suradnja iz polja metalurgije s nekoliko metalurških institucija iz zemalja EEZ-a na saveznoj razini. Suradnja se odvijala na projektu: Lijevanje i skrućivanje čelika (1980. - 1989.). Pri tome su se podnosili i izvještaji na sastancima u Bruxellesu, Sisku, Rimu, Düsseldorfu, Zenici, Smederevu, Sheffieldu i Ljubljani. U okviru suradnje sa zemljama SEV-a Metalurški fakultet je surađivao na temi: Dostignuća i tendencije u metalurgiji, a suradnja s WEB Röhrkombinat Riesa (Njemačka) odvijala se na temama koje se odnose na područje čeličnih cijevi, povišenje tehničke razine metalurških postrojenja i bolje iskorištenosti sekundarnih energetskih izvora (1980. - 1986.). Metalurški fakultet bio je koordinator (1982. - 1983.) znanstveno-tehničke suradnje svih jugoslavenskih željezara sa željezarama Demokratske Republike Njemačke (DDR). Metalurški fakultet je proširio međunarodnu suradnju i s Metalurškim fakultetom Visoke tehničke škole iz Košica (kasnije Tehničko sveučilište u Košicama, Slovačka), Metalurškim institutom iz Dnjepropetrovska (Ukrajina) na zajedničkim višegodišnjim istraživačkim projektnim temama itd. Organizirano je više seminara s međunarodnim sudjelovanjem iz pojedinih disciplina, npr. Problemi analitičke kemije u metalurgiji (1981. - Malinska, 1989. - Rogaška Slatina) kao i stručnih usavršavanja inženjera metalurgije: Problemi pri primjeni novih tehnologija (Malinska, 1982.), Stanje i razvojne tendencije proizvodnje čeličnih cijevi (Sisak, 1989.) itd.

Stupanjem na snagu Zakona o poduzećima (1989.) dolazi do reorganizacije Zeljezare Sisak, tako da Institut za metalurgiju postaje Istraživačko-razvojni institut (1989.) s Metalurškim fakultetom kao sektorom (bez pravne osobnosti), a istodobno ostaje članicom Sveučilišta u Zagrebu. Tim reorganizacijskim promjenama gotovo je potpuno napušten znanstveno-istraživački rad u Zeljezari Sisak, a istraživanja u okviru preostalog Istraživačko-razvojnog instituta d. o. o. nakon 1991. godine primarno su usmjerena na "rutinske" analize za potrebe pojedinih pogona te na stručne aktivnosti u okviru Željezare Sisak (slika 5). To potvrđuju i podatci iz bibliografija ${ }^{20,21}$ jer je nakon tih reogranizacijskih promjena drastično smanjena publicistička djelatnost zaposlenika Željezare Sisak u polju metalurgije. Dio znanstveno-istraživačke opreme (peći za toplinsku obradu, Jominy uređaj za ispitivanje prokaljivosti, SEM, torzioni plastometar, kidalica Zwick 50 kN, dilatometar LK02 itd.) nakon "raspada" Instituta za metalurgiju Željezare Sisak instaliran je na Metalurškom fakultetu.

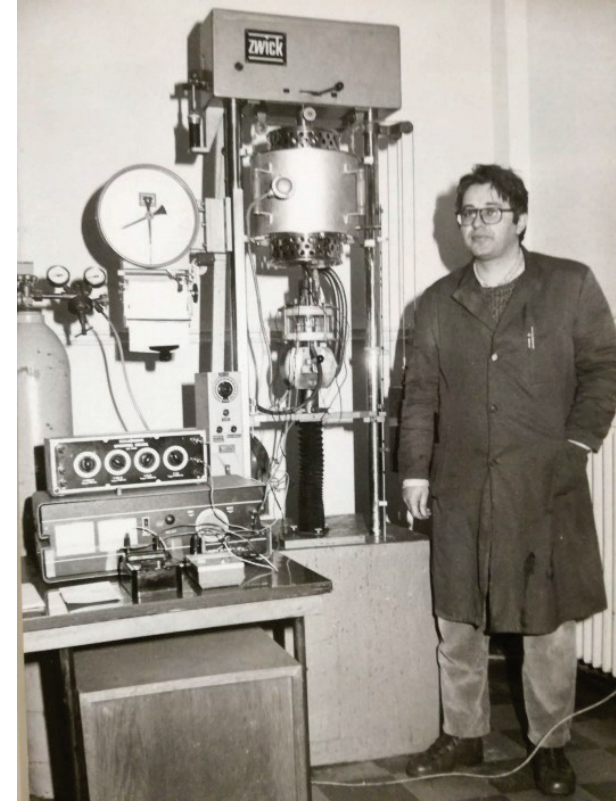

Slika 5 - Ispitivanje vodikove krhkosti čelika pod naprezanjem metodom katodne polarizacije u IRI d. o. o. Željezare Sisak (1994.)

Fig. 5 - Testing of hydrogen embrittlement under stressing by cathodic polarization method in IRI Ltd. Sisak Iron and Steel Works (1994)

U razdoblju od 1979. do 1. lipnja 1991. godine 137 studenata završilo je II. stupanj, stekavši zvanje dipl. ing. metalurgije. Za to vrijeme pet generacija (82 studenta) upisalo je I. stupanj metalurškog smjera, a 25 studenata steklo je višu stručnu spremu, odnosno akademsko zvanje inženjera metalurgije. Na poslijediplomski III. stupanj na Metalurškom fakultetu upisale su se četiri generacije s ukupno 65 studenata. Obranjena su 24 magistarska rada te 11 disertacija iz znanstvenog polja metalurgije. Za vrijeme djelovanja Metalurškog fakulteta u okviru Zeljezare Sisak stečeno je ukupno 186 akademskih zvanja i 11 akademskih stupnjeva doktora znanosti iz polja metalurgije.

\section{Metalurški fakultet Sveučilišta u Zagrebu}

Od 1. lipnja 1991. godine Metalurški fakultet postaje samostalna znanstveno-nastavna organizacija Sveučilišta u Zagrebu u polju metalurgije. Od tada Metalurški fakultet postaje samostalni pravni subjekt. Mijenja se i unutarnja organizacija, tj. sve se aktivnosti odvijaju u okviru dva zavoda: Zavod za materijale (sa šest laboratorija i jednom katedrom) i Zavod za metalurgiju (s pet laboratorija i jednom katedrom). ${ }^{22}$ Tada od 127 zaposlenika na Metalurškom fakultetu ostaje raditi 40 djelatnika (od kojih su 32 djelatnika izabrana u znanstveno-nastavnom i nastavnom zvanja), a angažirano je i osam vanjskih suradnika za nastavni proces. Nastava se odvija na dodiplomskom i poslijediplomskom magistarskom studiju metalurgije. Od 1. listopada 1997. godine pa sve do danas djelatnosti Metalurškog fakulteta odvijaju se kroz tri zavoda (Zavod za procesnu metalurgiju, 
Zavod za mehaničku metalurgiju i Zavod za fizičku metalurgiju) s odgovarajućim laboratorijima i jednom katedrom (Katedra za matematiku i informatiku). Planira se osnivanje Centra za ljevarstvo - SIMET kao nove ustrojstvene jedinice na temelju infrastrukturnog projekta financiranog $u$ okviru Europskog fonda za regionalni razvoj: Centar za ljevarstvo - SIMET (2019. - 2022.). ${ }^{23}$

Nastavna, znanstveno-istraživačka i stručna aktivnost Metalurškog fakulteta odvija se u dvije zgrade (slika 1) na istoj lokaciji (glavna zgrada površine $2208 \mathrm{~m}^{2}$ i dvorišna zgrada $1020 \mathrm{~m}^{2}$ ). Unatoč svim promjenama i teškoćama nastava se uvijek redovito odvijala, čak i u ratnim uvjetima (1991./92. - 1994./95.), u reduciranom obliku u skloništima Metalurškog fakulteta i podrumima grada Siska. ${ }^{24}$ Metalurški fakultet je akad. god. 2000./01. obnovio nastavni plan i program dodiplomskog četverogodišnjeg studija metalurgije i poslijediplomskoga znanstvenog magistarskog studija metalurgije prilagođen ECTS-u (engl. European Credit Transfer System - Europski sustav prijenosa bodova). Dodiplomski studij odvijao se kroz zajedničke programske osnove tijekom sedam semestara, s mogućnošću izbora jedne od tri izborne skupine predmeta (procesna metalurgija, ljevarstvo, prerada metala) u VIII. semestru.

Od akad. god. 2005./06. uveden je tzv. bolonjski proces studiranja. Uveden je dvorazinski 3-godišnji preddiplomski (od akad. god. 2012./13. sa smjerovima: Metalurško inženjerstvo i Industrijska ekologija) i 2-godišnji diplomski sveučilišni studij Metalurgija (od akad. god. 2017./18. s usmjerenjima: Metalurško inženjerstvo i Industrijska ekologija). Od akad. god. 2007./08. uveden je 3-godišnji poslijediplomski doktorski studij Metalurgija (30. rujna 2022. godine je krajnji rok završetka tog studija), a od akad. god. 2011./12. uveden je preddiplomski sveučilišni stručni izvanredni studij Ljevarstvo (studij traje pet semestara). Od akad. god. 2014./15. Metalurški fakultet izvodi, zajedno s Fakultetom strojarstva i brodogradnje, sveučilišni poslijediplomski doktorski studij Strojarstvo, brodogradnja, zrakoplovstvo, metalurgija, a zastupljen je s Metalurškim inženjerstvom kao jednim od 11 smjerova. Studij traje šest semestara (180 ECTS bodova), a završetkom se stječe akademski stupanj doktora tehničkih znanosti iz polja metalurgije. Svi navedeni studijski programi su reakreditirani i od nadležnog ministarstva dobivena je potvrda o ispunjavanju uvjeta za njihovo izvođenje. Osim toga, od akad. god. 2019./20. Metalurški fakultet izvodi i preddiplomski sveučilišni studij Sigurnost, zdravlje na radu i radni okoliš. Studijski program traje tri godine, a završetkom studija stječe se akademski naziv sveučilišni prvostupnik inženjer sigurnosti, zdravlja na radu i radnog okoliša (univ. bacc. ing. sec.).

U razdoblju od 1991. do 2013. godine znanstvena istraživanja provela su se kroz 20 znanstvenih projekata financiranih od nadležnog ministarstva. ${ }^{9}$ Istraživanja su se odvijala u područjima lijevanja, plastične deformacije, separacije metala, toplinske obrade, degradacije materijala te razvoja novih materijala (Ti-legure, legure s prisjetljivosti oblika itd.), uključujući uštedu energije i zaštitu okoliša itd. Treba izdvojiti istraživanja (2007. - 2013.) na znanstvenom programu Metalurškog fakulteta: Metalni materijali-svojstva, obrada i utrošak energije u koji su bila uključena četiri znanstvena projekta (tzv. z-projekti): Energetska učinkovitost $i$ kvaliteta proizvoda u plastičnoj defor- maciji metala, Okolišem potpomognuta degradacija metala i adsorpcija na otpadnim C-materijalima, Utjecaj visokotemperaturnih procesa na svojstva visokolegiranih čelika, Struktura, svojstva i separacija metalnih materijala. Istom istraživačkom razdoblju mogu se pridodati i samostalni znanstveni projekt izvan programa Metalurškog fakulteta (Skrućivanje metalnih odljevaka) i znanstveni projekt (Napredni postupci i simulacije u oblikovanju deformiranjem novih materijala) u okviru znanstvenog programa FSB-a iz Zagreba. U razdoblju 1998. - 2008. nabavljen je i najveći dio znanstveno-istraživačke opreme, kao npr.: uređaji za metalografsku pripremu uzoraka, svjetlosni mikroskop Olympus GX71 s digitalnom kamerom DP70 i programskim paketom (OLYMPUS Image Analysis Software) za kvantitativnu analizu slike, mikrotvrdomjer LEICA WMHT, makrotvrdomjer Vickers, potenciostat/galavanostat/FRA, simultani toplinski analizator STA DSC/TG DTA/TG, atomski apsorpcijski spektrometar s grafitnom tehnikom, sustav za toplinsku analizu-ATAS, analizator kisika u talinama željeznih lijevova (slika 6), SEM\&EDX (slika 7), simulacijski program ProCast, ThermoCalc računalni program itd., uz pomoć nadležnog ministarstva, donacijama, ali i uz znatan udio vlastitih sredstava (49,6\%), posebice zahvaljujući voditeljima znanstvenih i stručnih projekata koji su sudjelovali u solidarnoj nabavi kapitalne, srednje i opreme male vrijednosti. Dio znanstveno-istraživačke opreme dobiven je iz bivšeg Instituta za metalurgiju (slike 4 i 8). Znanstvena istraživanja u posljednjih 20-ak godina odvijala su se putem deset međunarodnih projekata (EUREKA program, bilateralni projekti itd.) i dva istraživačka projekta financirana od HRZZ-a: Dizajniranje mikrostrukture i funkcionalnih svojstava legura s prisjetljivosti oblika na bazi bakra (2015. - 2019.) i Istraživanja početka plastičnog toka metala kod hladne deformacije (2017. - 2020.). Oba projekta financirana od HRZZ-a uspješno su realizirana i vrednovana ocjenom A.

U razdoblju od 2013. do 2019. godine znanstveno-istraživački rad odvijao se i kroz 32 kratkoročne (jednogodišnje) potpore i šest jednogodišnjih institucijskih projekata (2019.)

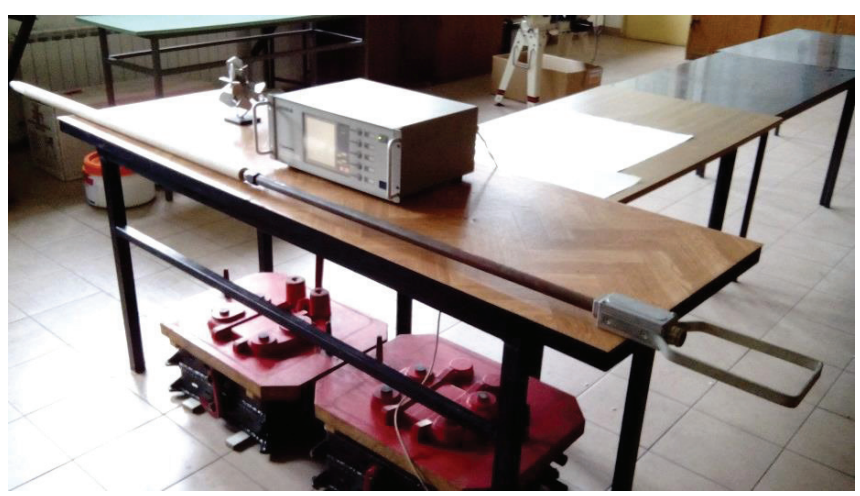

Slika 6 - Analizator kisika u talinama željeznih ljevova (Heraus Electro-Nite Multi-Lab III Celox®) u Laboratoriju za željezo, čelik i ljevarstvo Zavoda za procesnu metalurgiju Metalurškog fakulteta u Sisku (2010.)

Fig. 6 -Oxygen analyser for measuring oxygen content of cast iron melt (Heraus Electro-Nite Multi-Lab III Celox $®$ ) at the Iron, Steel and Casting Laboratory, Process Metallurgy Department of the Sisak Faculty of Metallurgy (2010) 


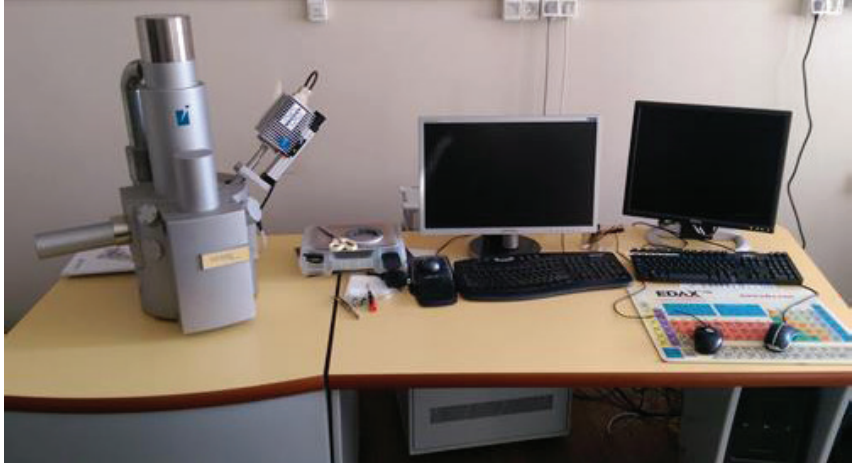

Slika 7 - Pretražni elektronski mikroskop (SEM) s energijsko disperzijskim spektrometrom (TESCAN VEGA $5136 \mathrm{MM}$ ) u Laboratoriju za fiziku i strukturna ispitivanja Zavoda za fizičku metalurgiju Metalurškog fakulteta u Sisku (2010.)

Fig. 7 - Scanning electron microscopy (SEM) with energy dispersive spectroscopy (TESCAN VEGA 5136 MM) at the Physics and Structure Testing Laboratory, Physical Metallurgy Department of the Sisak Faculty of Metallurgy (2010)

financiranim sredstvima dobivenim za temeljno financiranje znanstvene i umjetničke djelatnosti Sveučilišta u Zagrebu. Prioritetne teme znanstvenih istraživanja u posljednjih 10-ak godina u skladu su sa Strategijama razvoja Metalurškog fakulteta s dva strateška razvojna smjera: "Metalurško inženjerstvo i Industrijska ekologija" te "Inženjerski metalni materijali", te sa strateškim smjerovima istraživanja u RH u smjeru lijevanja i razvoja naprednih materijala, plastične deformacije, zaštite okoliša, istraživanja energetske učinkovitosti itd. Određeni dio znanstveno-istraživačke opreme je zastario, a dio opreme koji je dobiven od bivšeg Instituta za metalurgiju već je amortiziran. Očekuje se da će se u okviru infrastrukturnih projekata u okviru EFRR-a koji su u realizaciji: Centar za ljevarstvo - SIMET (2019. - 2022.) i VIRTULAB - Integrirani laboratorij za primarne i sekundarne sirovine (2018. - 2020.) podići razina infrastrukture, nabaviti nova i adaptirati starija znanstveno-istraživačka oprema. Time bi se podigla razina nastavnog procesa, povećala znanstveno-istraživačka i stručna djelatnost te osigurali bolji uvjeti za transfer znanja i tehnologija prema realnom gospodarskom sektoru. Razvoju polja metalurgije oduvijek je doprinosila suradnja koja je utemeljena na nizu potpisanih ugovora/protokola o suradnji s inozemnim i nacionalnim visokoškolskim i znanstvenim institucijama. Na primjer, na temelju protokola o petogodišnjoj suradnji od 1980. do 2005. godine Metalurškog fakulteta i Tehničkog sveučilišta u Košicama u koautorstvu su objavljena 62 članka u časopisima i 28 radova u zbornicima konferencija. ${ }^{25}$ Dobra se suradnja s ciljem održavanja i razvoja polja metalurgije u posljednjih 20-ak godina odvijala i s lokalnom zajednicom (Sisačko-moslavačka županija), HGK - Županijska komora Sisak, ali i s nizom gospodarskih subjekata, posebno iz ljevarstva u RH itd. Navedena suradnja manifestirala se u zajedničkim prijavama projekata, organizaciji seminara i radionica itd.

Od 2001. godine stručne aktivnosti Metalurškog fakulteta u polju metalurgije odvijale su se putem šest ugovorenih

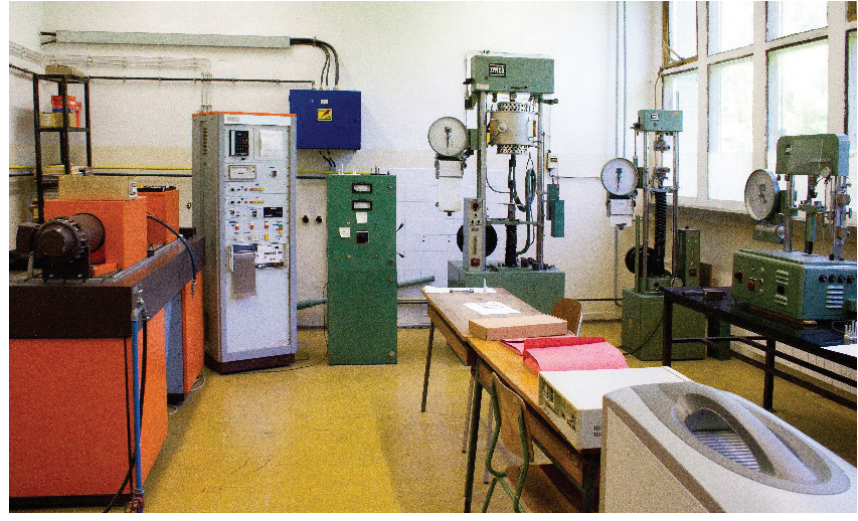

Slika 8 - Oprema Laboratorija za obradu kovina deformiranjem Zavoda za mehaničku metalurgiju Metalurškog fakulteta u Sisku (2010.)

Fig. 8 - Equipment of the Metal Deformation Laboratory, Mechanical Metallurgy Department of the Sisak Faculty of Metallurgy(2010)

tehnologijskih projekata (u okviru programa Hitra, Strip, Test, Razum i sl.) koje je financiralo nadležno ministarstvo: Kalibrir valjci (2001. - 2003.), Proizvodnja brodskih sidara (2002. - 2003.), Studija izvodljivosti Centra za razvoj ljevarstva (2002. - 2003.), Zbrinjavanje otpada crne metalurgije i ispitivanje mogućnosti njegove oporabe (2002. - 2006.), Poboljšani postupak lijevanja blokova i trupaca od gnječljivih aluminijskih legura (2003. - 2007.) i Izrada $i$ ispitivanje funkcionalnosti motora s rotirajućim kućištem (2006. - 2009.). ${ }^{9}$ Realizirani su projekti i zadatci ugovoreni za potrebe gospodarskih subjekata iz metalurške (TLM Šibenik itd.) i metaloprerađivačke industrije te su izrađeni i brojni stručni izvještaji, posebno iz ljevaonica.

Na osnovi provedenih istraživanja u razdoblju od 1991. do 2019. godine na Metalurškom fakultetu objavljeno je oko 760 znanstvenih i stručnih radova u domaćim (Metalurgija, Ljevarstvo, Kemija u industriji itd.) i međunarodnim časopisima (Materials and Technology, Livarski vestnik, Journal of Alloys and Compounds itd.) te oko 640 radova u zbornicima s međunarodnih i domaćih skupova. Izrađene su i stručne ekspertize i brojni stručni izvještaji za niz gospodarskih subjekata iz polja metalurgije i srodnih znanstvenih polja.

U razdoblju od 1. lipnja 1991. do 19. prosinca 2011. godine 129 studenata steklo je zvanje dipl. ing. metalurgije, pet studenata steklo je akademsko zvanje inženjera metalurgije, 14 studenata obranilo je magisterije, a 13 studenata obranilo je disertacije. Do 31. prosinca 2019. godine, u skladu s bolonjskim procesom, 112 studenata steklo je akademsko zvanje sveučilišni prvostupnik-inženjer metalurgije, 58 magistara inženjera metalurgije i osam stručnih prvostupnika ljevarstva, a tri studenta obranila su disertacije. Sumarno, u okviru djelovanja Metalurškog fakulteta kao samostalne sastavnice Sveučilišta u Zagrebu od 1. lipnja 1991. do 31. prosinca 2019. godine stečeno je 365 akademskih zvanja i 16 akademskih stupnjeva doktora znanosti iz polja metalurgije. 


\section{Aktivnosti iz polja metalurgije na drugim institucijama i u okviru strukovnih društava}

Pored institucija iz Siska i Instituta za lake metale iz Zagreba značajan doprinos razvoju polja metalurgije dolazi i od današnjih tehničkih fakulteta u Republici Hrvatskoj: FSB iz Zagreba, FESB iz Splita, TF iz Rijeke i SF iz Slavonskog Broda od njihova osnivanja. To se odnosi na odjele, zavode, katedre i laboratorije tih fakulteta koji su dijelom ili usko vezani uz polje metalurgije (lijevanje, obrada deformiranjem, zavarivanje, toplinska obrada itd.). Nastava iz ljevarstva i oblikovanja metala deformiranjem (u obliku pojedinačnih predmeta) odvija se i na svim navedenim fakultetima od njihova osnivanja. Navedeni fakulteti sudjeluju i u znanstveno-istraživačkom i stručnom radu samostalno i/ ili u suradnji s drugim institucijama te u organizaciji seminara, primarno iz ljevarstva. Najveća institucija s najznačajnijim doprinosom od navedenih ostalih visokoškolskih institucija u polju metalurgije je FSB iz Zagreba ("majka" i/ ili podupiratelj ostalih osnovanih tehničkih fakulteta iz polja strojarstva) na kojem se u okviru današnjih zavoda: za materijale, za zavarene konstrukcije i za tehnologiju (ranije su to bile organizacijske jedinice različitih naziva), posebno na Katedri za ljevarstvo kao i na Katedri za oblikovanje deformiranjem. Zavod za materijale bavi se ispitivanjem metalnih materijala (čelici, željezni lijevovi, obojeni metali), razvojem i primjenom postupaka toplinske obrade $\mathrm{i}$ inženjerstva površina itd. Zavod za zavarene konstrukcije bavi se zavarljivosti čelika i obojenih metala, osposobljavanjem prema programu Europske federacije za zavarivanje itd. Katedra za ljevarstvo bavi se istraživanjima svojstava kalupnih mješavina, livljivosti metala, toplih napuklina i uljevnih sustava, tehnikama lijevanja u pijesku, lijevanjem u semisolid stanju itd. ${ }^{26,27} \mathrm{U}$ istraživanja u ljevarstvu uvode se suvremene znanstvene metode planiranja pokusa optimalizacije, simulacije elektronskim računalom itd. Katedra za oblikovanje deformiranjem bavi se istraživanjima na oblikovljivosti materijala, strojeva za oblikovanje materijala deformiranjem, modelskim i prototipnim istraživanjima $\mathrm{u}$ postupcima valjanja, istiskivanja, provlačenja i dubokog vučenja ${ }^{27}$ i sl. Predavali su se ili predaju predmeti: Ljevarstvo, Obrada deformiranjem itd. Neki od realiziranih znanstveno-istraživačkih projekata, tema i zadataka bliski polju metalurgije na FSB-u Zagreb su npr.: Proučavanje i osvajanje novih legura (1969. - 1970.), Termička obrada metala u vakuumu (1969. - 1970.), Razvoj i unapređenje aluminijske industrije (1972. - 1975.), Livljivost materijala (1972.), Razvoj i unapređenje ljevarstva (1979.), Razvoj i istraživanje obrade deformacijom (1979.), Optimalizacija MIG/MAG zavarivanja (1979.), Fotoplastično modeliranje postupaka oblikovanja deformiranjem (1991. - 1995.), CAM tehnologije i modeliranje u oblikovanju deformiranjem i mikrooblikovanju (2007. - 2013.) itd. ${ }^{27}$ Znanstvena i stručna aktivnost Zavoda za proizvodno strojarstvo na FESB-u u Splitu sastoji se, osim ostalog, od izučavanja postupaka obrade aluminija valjanjem i istiskivanjem, zavarivanja, toplinske obrade alatnih čelika i ADI (Austempering Ductile Iron) ljevova itd. Na TF-u u Rijeci neki od znanstveno-istraživačkih projekata su: Svojstva i primjena materijala (1981. - 1985.), Istraživanje i razvoj metalnih materijala (1986. - 1990.), Optimiranje parametara i predviđanje rezultata toplinske obrade metala (2017. - 2013.) itd. ${ }^{28}$ Na SF-u u Slavonskom
Brodu zaposlenici Zavoda za proizvodno strojarstvo bave se zavarivanjem, lijevanjem i oblikovanjem materijala deformiranjem, a neki od znanstveno-istraživačkih projekata su: Visokočvrsti čelici (1979. - 1989.), Analiza tehnologičnosti zavarenih konstrukcija (1996. - 2001.), Primjena matrice defektabilnosti u ljevaoničkoj industriji (2007. - 2013.) itd. ${ }^{29}$ Također, pojedini instituti i/ili laboratoriji u okviru velikih gospodarskih subjekata (npr. TLM Šibenik, Institut "Đuro Đaković" Slavonski Brod, Institut Jugoturbine Karlovac itd.) dali su određeni doprinos razvoju polja metalurgije praćenjem kvalitete $\mathrm{i}$ analize poluproizvoda i gotovih proizvoda iz metalnih materijala. Treba istaknuti da je u okviru TLM-a Šibenik 1985. godine osnovan Centar za aluminij (CAL) kao nositelj znanstvenog, stručnog i obrazovnog rada. Ciljevi CAL-a su uvođenje novih proizvoda i tehnologija, predlaganje rekonstrukcija i modernizacija postojećih postrojenja ili izgradnja novih pogona, efikasnija uporaba svih vrsta energije, planiranje i izobrazba kadrova, izrada prototipova i ispitivanje svojstava aluminija i aluminijskih legura, zaštita okoliša, objedinjavanje i izdavanje stručne dokumentacije, stanardizacija proizvoda i kontrola kvalitete itd. CAL je imao četiri laboratorija i više grupa ili odjela s 95 zaposlenika, od kojih su 32 imala visokostručnu spremu. Godine 1989. u okviru CAL-a osnovan je Istraživačko-proizvodni pogon s ciljem uvođenja novih proizvoda i novih tehnoloških procesa u proizvodnji i preradi aluminija, za prototipnu radionicu, proizvodnju "nulte" serije proizvoda, simulacije i metalurških procesa itd. Kasnije je CAL ustrojen kao TLM-CAL d. o. o. te smanjuje istraživačku djelatnost i usmjerava se na pružanje laboratorijskih, energetskih i ekoloških usluga te na projektiranje i izgradnju novih proizvodnih pogona kao i na uvođenje sustava osiguranja kvalitete u TLM-u Šibenik. Osim toga, svoju djelatnost sve više usmjerava prema vanjskom tržištu za proizvodnju aluminijske građevinske bravarije (kiosci), Al-stolarije itd. Zaposlenici CAL-a, u suradnji s Metalurškim fakultetom Sisak i drugim visokoškolskim (FSB iz Zagreba, FESB i Kemijsko tehnološki fakultet iz Splita) i domaćim i međunarodnim znanstvenim institucijama, zajedno s nadležnim ministarstvom, sudjelovali su u istraživačkim tehnologijskim projektima: Tanke trake iz slitina 5052 za duboko izvlačenje, namijenjene ambalaži u ribljoj, mesnoj i farmaceutskoj industriji, Razvoj polukontinuirano lijevanih poluproizvoda od gnječljivih aluminijskih slitina itd. CAL 1990. godine postaje Sektor za istraživanje i razvoj i djelovao je do 2009. godine.

Za razvoj polja metalurgije bitan je i doprinos odgovarajućih strukovnih društava s ciljem organiziranja savjetovanja, simpozija i stručnih seminara. Još 20. veljače 1953. godine osnovano je Društvo ljevača NR Hrvatske u Zagrebu, koje je povremeno organiziralo savjetovanja i seminare iz ljevarstva u Zagrebu na FSB-u, kao npr.: Savjetovanje proizvođača i potrošača sirovog gvožđa, lomljevine i koksa (1963.), Simpozij o žilavom lijevu (1968.), Transfer u tehnologiju (1974.), seminar: Klasifikacija i karakteristike lijevova na bazi željeza (1974.) itd. Društvo ljevača SR Hrvatske je organiziralo V. kongres ljevača Jugoslavije u Splitu (1977.), a tim je povodom izdan i jubilarni broj časopisa Ljevarstvo 24 (1977). Inicijator prvih savjetovanja i seminara iz ljevarstva u to vrijeme bio je prof. Niko Malešević (1901. - 1982.), dugogodišnji nastavnik FSB-a u Zagrebu (1946. - 1972.) te inicijator i jedan od osnivača Društva ljevača SR Hrvatske i časopisa Ljevarstvo. Odabrani radovi 
s kongresa ljevača objavljivali su se u časopisu Ljevarstvo, koji je počeo izlaziti od 1954. godine.

Udruga Društvo inženjera i tehničara (DIT) Sisak, posebno DIT Željezare Sisak (od 1952. godine) podupiralo je i potpomoglo razvoj polja metalurgije. To se manifestiralo organiziranjem povremenih stručnih tematskih tribina i predavanja iz niza polja (strojarstvo, elektrotehnika itd.) u području tehničkih znanosti, uključujući i polje metalurgije.

Treba napomenuti da je akademik Miroslav Karšulin jedan od osnivača nastavnog procesa i profesor na odjelima Tehnološkog fakulteta u Sisku inicirao osnivanje međunarodnog znanstvenog društva International Committee for the Study of Bauxite, Alumina and Aluminium (ICSOBA) 1963. godine u okviru JAZU-a. ${ }^{30}$ To je svjetsko društvo iz područja istraživanja eksploatacije boksita i srodnih ruda, prerade u glinicu i elektrolize u aluminij. Kongres se održava svakih pet godina. Prvi kongres održan je u Zagrebu 1963. godine, a kasnije je u Zagrebu održan i 1983. godine. Na prijedlog akademika M. Karšulina prihvaćeno je da se radovi s tog svjetskog simpozija publiciraju u časopisu Travaux de I'ICSOBA. Znanstvenici iz Republike Hrvatske aktivno su sudjelovali na toj konferenciji te su objavili oko desetak radova u časopisu Travaux de I'ICSOBA.

Hrvatsko metalurško društvo (HMD) osnovano je 6. travnja 1992. godine u Sisku. Od 1994. godine HMD svake dvije godine organizira međunarodni simpozij "Materijali i metalurgija". Za prva tri simpozija (1994. - 1998.), pored HMD-a, suorganizator je bio i Metalurški fakultet. U razdoblju 1994. - 2019. održano je 13 simpozija HMD-a u: Zagrebu (1994.), Splitu (1996.), Opatiji (2000.) i Šibeniku (1998., 2002. - 2018.). Sažeci radova i odabrani radovi se, nakon recenzentskog postupka, objavljuju u časopisu Metalurgija. Inicijator simpozija te predsjednik Organizacijskog odbora (1994. -) je prof. dr. sc. Ilija Mamuzić, dr. h. c., vanjski suradnik (1963. - 1978.) i dugogodišnji nastavnik Metalurškog fakulteta (1979. - 2010.), inicijator osnivanja i predsjednik HMD-a te glavni i odgovorni urednik časopisa Metalurgija (od 1985. -).

\section{Knjižnice i knjižni fond u znanstvenom polju metalurgije}

Za odvijanje visokoškolske nastave i razvoj znanstvenog polja metalurgije veliku ulogu imaju knjižnice sa svojim knjižnim fondom. Početkom djelovanja odjela u Sisku Tehnološkog fakulteta već 1961. godine osniva se stručna knjižnica, koja 1962. godine raspolaže s više od 4500 naslova knjiga i skripata. Primarna ideja bila je objedinjavanje knjižnične građe kako bi se na jednome mjestu moglo pronaći relevantne knjige i časopise iz polja metalurgije, kemije, kemijskog inženjerstva itd. Već 1964. godine knjižnica ima više od 7700 knjiga i skripata. Godine 1970. knjižnica raspolaže s više od 10000 knjiga, posebno iz metalurgije i prerade nafte na engleskom, njemačkom, ruskom i ostalim jezicima. Knjižnica raspolaže s 1446 godišta časopisa, a redovito prima 97 časopisa. ${ }^{8}$ Današnja knjižnica Metalurškog fakulteta sastoji se iz dva dijela: knjižnice i čitaoni- ce s pretprostorom $\left(90 \mathrm{~m}^{2}\right)$ te dijela za arhivu i spremišta knjižnice $\left(75 \mathrm{~m}^{2}\right)$. U okviru Knjižnice djeluje i Skriptarnica. Knjižnica je uređena i modernizirana (2007.) $)^{9}$ zahvaljujući donaciji Valjaonice cijevi Sisak d. o. o., koja je uz navedenu donaciju poklonila i 1196 naslova knjiga, niz uvezanih godišta znanstvenih i stručnih publikacija (Metalurgical Transactions, The British Foundryman, Ljevarstvo, Livarski vestnik itd.). Knjižnični fond Metalurškog fakulteta na dan 31. prosinca 2019. godine iznosio je 12120 knjiga. Knjižnica djeluje kao dio integriranog knjižničnog sustava Nacionalne i sveučilišne knjižnice (NSK) u Zagrebu i knjižnica iz sustava znanosti i visokog obrazovanja. Redovito dobiva na poklon dva metalurška časopisa (Metalurgija, Materiali in tehnologije), a pristup elektroničkim časopisima omogućen je putem Portala elektroničkih izvora.

Institut za metalurgiju u Sisku je u razdoblju 1961. - 1991. raspolagao sa Stručnom knjižnicom (ustrojena 1954. godine u okviru Željezare Sisak), koja nabavlja strane (na njemačkom, engleskom i ruskom jeziku) i domaće knjige (više od 10 000), udžbenike i skripta, brojne časopise (oko 1000 naslova na talijanskom, francuskom, njemačkom, engleskom i ruskom jeziku) iz polja metalurgije i srodnih polja u području tehničkih znanosti. Knjižnica, pored domaćih časopisa (Metalurgija, Strojarstvo, Ljevarstvo, Zavarivanje, Kemija u industriji itd.), nabavlja i metalurške časopise iz bivših republika Jugoslavije (Čelik, Železarski zbornik, Rudarsko-metalurški zbornik, Livarski vestnik, Varilna tehnika, itd.) kao i najznačajnije prestižne međunarodne časopise iz znanstvenog polja metalurgije (Revue de Metallurgie, Stahl und Eisen, Steel Research, Metallurgical Transactions A and B, Giesserei, Acta Metallurgica, Hutnické listy, Stal', Metallurg, La Metallurgia italiana, Metallovedenie i termicheskaya obrabotka metallov, Iron and Steel Engineer, Materials science and technology itd.). Za vrijeme djelovanja Metalurškog fakulteta u okviru Instituta za metalurgiju (1979. - 1991.) u okviru Stručne knjižnice Željezare Sisak, nastavljena je nabava novih knjiga, udžbenika, skripata te domaćih i međunarodnih časopisa. Stručna knjižnica Željezare Sisak djelovala je do 2007. godine. Prema posljednjem popisu 2002. godine, knjižni fond Stručne knjižnice sastojao se od ukupno 20490 svezaka knjiga i brošura. ${ }^{31}$ Od toga je referentna zbirka: 2356 svezaka enciklopedija, leksikona i priručnika i 950 rječnika. Zbirka časopisa sastojala se od 627 naslova u preko 8000 volumena. Postojala je i velika zbirka normi EU, ASME, ASTM, ISO itd. Stručna knjižnica sadržavala je referentne časopise: Referativni žurnal, Zeitschriften und Buecherschau-Stahl und Eisen, AnaIytical Abstracts, Corrosion Abstracts, Metals Abstracts itd. Dio knjižnog fonda predan je Narodnoj knjižnici i čitaonici Sisak, Državnom arhivu u Sisku i Metalurškom fakultetu u Sisku.

U okviru Željezare Split također je djelovala interna stručna knjižnica koja je prestala s radom stečajem željezare (2018.). Knjižnica TLM-a Šibenik djelovala je u razdoblju od 1956. do 2008. godine i bila je locirana u prostorima tvornice u Ražinama. Knjižnica je 1990. godine imala oko 5000 knjiga (oko 3300 stručnih knjiga iz područja rada tvornice) i dobivala je 90 domaćih (Kemija u industriji, Strojarstvo, Ljevarstvo, Metalurgija itd.) i međunarodnih časopisa (Light Metals, Metal Industry, The British Journal of Metals, Alluminio, Revue de Metallurgie itd.). ${ }^{32}$ 


\section{Izdavačka i publicistička djelatnost u znanstvenom polju metalurgije}

Razvojem znanstvenog polja metalurgija rasla je izdavačka i publicistička djelatnost u RH. U razdoblju 1960. - 2020. objavljeno je više od 3000 znanstvenih i stručnih radova (više od 2700 s institucija u Sisku i više od 300 s drugih institucija iz RH) u domaćim (Metalurgija, Ljevarstvo, Kemija u industriji, Strojarstvo, Zavarivanje itd.) i međunarodnim časopisima (Materials and Technology, Travaux de I'ICSOBA, Livarski vestnik, itd.) te zbornicima međunarodnih i domaćih konferencija. Kao rezultat stručnih aktivnosti izrađeno je više od 1000 elaborata, velik broj ekspertiza i brojni stručni izvještaji za gospodarske subjekte iz metalurgije i srodnih znanstvenih polja, registrirano je 20 -ak patenata itd. U tom razdoblju u polju metalurgije objavljeno je nekoliko monografija (npr. J. Črnko, D. Maljković: 40. obljetnica visokoškolske nastave metalurgije 1960. - 2000. i M. Gojić: 50 godina studija metalurgije 1960. - 2010., u izdanju Metalurškog fakulteta u Sisku), više od 50 knjiga i sveučilišnih udžbenika, niz poglavlja u knjigama, sedam zbornika (s cjelovitim radovima) i jedanaest zbornika sažetaka radova međunarodnog savjetovanja ljevača, brojna sveučilišna i interna skripta itd. Od izdavačke djelatnosti mogu se izdvojiti sljedeće knjige i udžbenici: L. Chloupek: Proizvodnja sirovog željeza (2. prošireno izdanje, Tehnička knjiga Beograd, 1964.), A. Tripalo: Tehnologija prerade aluminija (Tehnička knjiga, Beograd, 1966.), L. Chloupek: Metalurške peći s projektiranjem I i I/ dio (2. izdanje, Odjeli Tehnološkog fakulteta, Zagreb, 1970.), J. Hribar: Plastična obrada metala (Fakultet strojarstva i brodogradnje, Zagreb, 1975.), grupa autora: Ljevački priručnik (Savez ljevača Hrvatske, Zagreb, 1984.), P. Pavlović: Materijal čelik (SKTH/Kemija u industriji, Zagreb, 1990.), I. Mamuzić, V. Drujan: Teorija, materijali, tehnologija čeličnih cijevi (Hrvatsko metalurško društvo, Zagreb, 1996.), M. Novosel, D. Krumes: Posebni čelici (Strojarski fakultet, Slavonski Brod, 1998.), Z. Lukačević, Zavarivanje (Strojarski fakultet, Slavonski Brod, 1998.), B. Smoljan: Toplinska obrada čelika, sivog i nodularnog lijeva (Hrvatsko društvo za toplinsku obradu i inženjerstvo površina, Zagreb, 1999.), Z. Bonačić Mandinić, I. Budić: Osnove tehnologije kalupljenja-jednokratni kalupi 1-2 (Strojarski fakultet, Slavonski Brod, 2001.), M. Math, Uvod u tehnologiju oblikovanja deformiranjem (Fakultet strojarstva i brodogradnje, Zagreb, 2005.), M. Gojić: Metalurgija čelika (II. nepromijenjeno izdanje, Metalurški fakultet, Sisak, 2006.), V. Grozdanić, A. Markotić: Metalurgija željeza i čelika - zbirka riješenih zadataka (Hrvatska zajednica tehničke kulture i Metalurški fakultet, Sisak, 2006.), I. Duplančić: Obrada deformiranjem (Fakultet elektrotehnike, strojarstva i brodogradnje, Split, 2007.), D. Hršak: Hidrometalurgija (Metalurški fakultet, Sisak, 2008.), M. Gojić: Površinska obradba materijala (Metalurški fakultet, Sisak, 2010.), A. Rađenović: Vatrostalni materijali (Metalurški fakultet, Sisak, 2010.) itd.

Iskoraci u razvoju metalurške terminologije učinjeni su izradom rječnika iz polja metalurgije i tehničkog leksikona. Institut za metalurgiju u Sisku bio je nositelj zadatka izrade višejezičnog Metalurškog rječnika s oko 8000 metalurških termina objavljenog 1971. godine u izdanju UJŽ-a i izdavačkog poduzeća Građevinska knjiga u Beogradu. Od oko 50-ak suradnika na rječniku u 17 metalurški grupiranih disciplina iz crne metalurgije (sirovo željezo, čelik, lijevanje, fizička metalurgija, zavarivanje, kovanje, valjanje, ispitivanje materijala itd.) pri njegovoj izradi kao suradnici iz RH sudjelovali su profesori Lujo Chloupek, Ilija Mamuzić i Pavle Pavlović. Stručna metalurška terminologija iz ljevarstva predstavljena je u trojezičnom (hrvatsko-englesko-njemački) rječniku: M. Galić-Milas: Ljevarski rječnik (Hrvatsko udruženje za ljevarstvo, Zagreb, 1999.). Polje metalurgije terminološki je obrađeno i u Tehničkom leksikonu (Leksikografski zavod "Miroslav Krleža", Zagreb, 2007.), a suradnici za polje metalurgije bili su profesori Metalurškog fakulteta: Josip Črnko, Mirko Gojić, Marijan Golja, Darko Maljković, Prosper Matković i Faruk Unkić.

Razvoju polja metalurgije u publicističkom smislu u RH doprinijelo je postojanje časopisa Ljevarstvo (od 1954. do 2013., s iznimkom 1959. godine, kada zbog financijskih razloga nije tiskan) kao i ostalih domaćih časopisa iz tehničkog područja (Kemija u industriji, Strojarstvo, Zavarivanje, Nafta itd.). Razvoju polja metalurgije najviše je doprinijelo osnivanje časopisa Metalurgija (1962.). Svoj doprinos daje i organiziranje međunarodnih konferencija poput međunarodnog simpozija Hrvatskog metalurškog društva (HMD): "Materijali i metalurgija" (1994. -). Također doprinos daje međunarodno savjetovanje ljevača pod različitim tematskim nazivima (od 1999. godine) i znanstveno-stručnih seminara iz ljevarstva (od 2008.) koje organizira Metalurški fakultet. Inicijator međunarodnog savjetovanja ljevača i seminara te višegodišnji predsjednik organizacijskog odbora savjetovanja (1999. - 2014.) bio je prof. dr. sc. Faruk Unkić, dugogodišnji nastavnik Metalurškog fakulteta (1979. - 2014.) i glavni i odgovorni urednik časopisa Ljevarstvo (2003. - 2006., 2008. - 2013.). Kratki sažeci radova s dosadašnjih (1994. - 2019.) 13 međunarodnih simpozija HMD-a publicirani su u časopisu Metalurgija, a odabrani radovi su nakon recenzentskog postupka objavljeni u časopisu Metalurgija. Cjeloviti radovi s međunarodnog savjetovanja ljevača tiskani su u sedam zbornika radova (1999. - 2006.), od 2008. godine tiska se Zbornik sažetaka (2008. - 2019.), a cjeloviti radovi objavljeni su na CD-ROM-u. Odabrani radovi sa savjetovanja ljevača nakon recenzentskog postupka objavljivani su u časopisu Ljevarstvo, dok se tiskao (2013.). Od 2015. godine radovi sa znanstveno-stručnih seminara iz ljevarstva tiskaju se u Knjizi sažetaka.

Časopis Ljevarstvo počeo je izlaziti 1954. godine u izdanju Društva ljevača NR Hrvatske kao njegovo glasilo. Te je godine objavljen samo jedan broj s 12 stručnih radova s Tehničkog fakulteta i ljevaonica. U početku (1955. i 1956.) časopis je objavljivao godišnje 40-ak radova. Tijekom vremena časopis je mijenjao imena: Ljevarstvo (1954. - 1986.), Livarstvo (1986. - 1992.) i Ljevarstvo (1992. - 2013.), a bili su i različiti izdavači. U razdoblju 1954. - 1962. časopis je izdavalo Društvo ljevača NR Hrvatske (osim što 1959. godine nije izašao niti jedan broj), zatim Društvo ljevača SR Hrvatske (1963. - 1977.), Savez ljevača SR Hrvatske iz Rijeke (1978. - 1986.), Savez organizacija livaca Jugoslavije (1986. - 1991.), Savez ljevača Hrvatske (1992. - 1995.). Od 1995. godine do prestanka izdanja (2013.) časopis Ljevarstvo bio je glasilo Hrvatskog udruženja za ljevarstvo. Casopis Ljevarstvo objavljivao je znanstvene i stručne radove iz ljevarstva, davao prikaze iz higijensko-tehničke zaštite te priloge iz prakse, posjeta ljevaonicama, povijesnih tema iz razvoja ljevarstva te prenosio najnovija saznanja i informacije iz ljevarstva iz međunarodne znanstvene i stručne periodike (La Fonderia Italiana, Giesserei itd.). S vremenom 
se broj objavljenih radova na godišnjoj razini smanjivao (najčešće 2 - 3 rada po broju) i objavljivao je radove samo iz ljevarstva. U prvih 10 godina izdanja časopisa Ljevarstvo primarne sadržajne cjeline su: opće ljevarstvo, tehnike izrade modela, ljevački pijesci i bentonitne gline, tehnika izrade kalupa itd. Od 1999. godine kada se održava međunarodno savjetovanje ljevača u organizaciji Metalurškog fakulteta odabrani radovi se, nakon recenzentskog postupka, tiskaju u časopisu Ljevarstvo do kraja njegova izdavanja (2013.). Prestanak izlaženja časopisa Ljevarstvo u 2013. godini posljedica je složenih djelovanja više čimbenika uključujući funkcioniranje i/ili nefunkcioniranje Hrvatskog udruženja za ljevarstvo, prestanka financiranja nadležnog ministarstva, nedovoljnog broja dostavljenih rukopisa radova za tiskanje, gospodarskog stanja ljevaonica itd.

Pokretanjem časopisa Metalurgija 1962. godine u Sisku bilo je, u publicističkom smislu, presudno za razvoj polja metalurgije. Osim toga, treba napomenuti da je časopis Metalurgija bitan časopis i za izbore u zvanja, ne samo u polju metalurgije nego i u ostalim poljima u području tehničkih znanosti u RH, regiji, ali i šire. Velika većina znanstveno-nastavnog osoblja na Metalurškom odjelu i OOUR-u Metalurškog inženjerstva Tehnološkog fakulteta, odnosno kasnije na Metalurškom fakultetu Sveučilišta u Zagrebu izabrana je u zvanja zahvaljujući objavljenim radovima u časopisu Metalurgija. Osnivač časopisa Metalurgija (1962.) je Društvo inženjera i tehničara (DIT) Željezara Sisak. Prve godine objavljen je jedan broj s tri stručna rada (autori su zaposlenici Željezare Sisak). ${ }^{33}$ Broj radova u časopisu Metalurgija postupno se povećava jer objavljuje radove iz pripreme ruda, ekstraktivne metalurgije, prerade te ispitivanja i kontrole sirovina, poluproizvoda i gotovih proizvoda itd. Časopis se redovito tiska do danas, a na internetskim stranicama dostupni su izdani brojevi od 2001. godine. ${ }^{34} \mathrm{U}$ razdoblju od 1965. do 1978. godine časopis Metalurgija bio je stručno glasilo odjela u Sisku Tehnološkog fakulteta Sveučilišta u Zagrebu, Instituta za metalurgiji u Sisku i Željezare Sisak. Metalurški fakultet bio je izdavač (1979. - 1984., 1991. - 1992., br. 1), a u razdoblju od 1992. (br. 2) do 1994. godine suizdavač časopisa Metalurgija zajedno s HMD-om, koji je osnovan 1992. godine. Nakon toga, tj. od 1995. godine HMD je jedini izdavač časopisa Metalurgija. Časopis Metalurgija objavljuje znanstvene i stručne radove (iz svih grana polja metalurgije i drugih srodnih znanstvenih polja), prikaze i sl. Većina radova (69 \%) u prvih 15 godina izlaženja časopisa Metalurgija je iz područja crne metalurgije, gdje su ekstraktivna metalurgija, prerada i kontrola uglavnom zastupljene $u$ istom omjeru. ${ }^{35}$ Tijekom prvih 25 godina izdavanja časopisa Metalurgija $67 \%$ autora publiciranih članaka je iz RH (primarno iz Siska: odjeli u Sisku Tehnološkog fakulteta, Institut za metalurgiju Sisak i Željezara Sisak), $22 \%$ autora iz ostalih republika bivše Jugoslavije, a $11 \%$ iz inozemstva. ${ }^{20}$ Gašenjem Instituta za metalurgiju (krajem 1980.-ih godina) i smanjenjem aktivnosti bivše Željezare Sisak časopis Metalurgija od tada nije primarno namijenjen stručnim potrebama u proizvodnji čelika i njegovoj obradi i preradi u RH, nego se priklonio uglavnom znanstvenoj produkciji zemalja Srednje i Istočne Europe. ${ }^{33}$ To potvrđuje i analiza za posljednjih 10 godina (2010. - 2019.) ${ }^{34}$ pokazavši da su u časopisu Metalurgija primarno zastupljeni autori/koautori iz inozemstva (89,3 \%). U istom razdoblju zastupljenost radova iz RH je 10,7 \% (1,0 \% radova objavili su zaposlenici Metalurškog fakulteta kao jedine nastavne i preostale znanstveno-istraživačke institucije iz polja metalurgije u RH). U posljednjem desetljeću (2010. - 2019.) djelatnici Metalurškog fakulteta ukupno su objavili 254 rada u časopisima. ${ }^{36}$ Analiza dostupnih podataka ${ }^{36} \mathrm{u}$ tom razdoblju ukazuje na to da je orijentacija znanstveno-nastavnog osoblja Metalurškog fakulteta usmjerena primarno prema publiciranju rezultata znanstveno-istraživačkog rada u međunarodnim časopisima: Materiali in tehnologije, Livarski vestnik, RMZ-Materials and geoenvironment, Journal of mining and metallurgy. Section: B Metallurgy, Kovové materiály, Journal of alloys and compounds itd.

Također, razvoju polja metalurgije dali su časopisi Strojarstvo i Zavarivanje u kojima su objavljeni brojni matalurški članci i prilozi. Na primjer, u časopisu Strojarstvo objavljeni su radovi: Ljevačka metalurgija bakrenih slitina (1964.), Toplinska obrada aluminijskih slitina i njena stabilizacija (1973.), Ispitivanje prokaljivosti čelika za cementiranje (1976.), Ljevarstvo SR Hrvatske (1977.) itd. Disciplina Metalurgija zavarivanja obrađena je u četiri broja časopisa Zavarivanje (1966.), a u okviru priloga tzv. "škola zavarivanja" obrađeno je polje metalurgije za zavarivače u 14 brojeva časopisa Zavarivanje (1969. - 1970.) itd.

Treba spomenuti da je u okviru Željezare Sisak izlazio mjesečni Bilten Željezare Sisak (studeni 1952. - svibanj 1953.), Metalurg (lipanj 1952. - 1953.), a od 1954. do 1995. godine izlazio je dvotjedni list Vjesnik Željezare, koji je, osim ostalog, pružao informacije i stručne priloge iz metalurške proizvodnje, otvaranja novih pogona, ugradnje nove opreme, srednjoškolskog (ljevač, procesni metalurg, valjač, metalurški tehničar itd.) i visokoškolskog obrazovanja, inovativnog rada itd. Kao nadopuna Vjesnika Željezare od 1983. godine mjesečno je izlazio list Željezarac, čiji je izdavač bi Metaval kao najveća metalurška radna organizacija Željezare Sisak. Također u okviru TLM-a Šibenik (1963. - 2004.) mjesečno je izdavan list Aluminij kao glasilo TLM-a, koji je, pored ostalog, donosio tehničke priloge s temama, npr.: uvođenja novih Al-legura, načina lijevanja, ustrojstva laboratorija itd. U TEF-u Šibenik od 1962. godine također je izlazio tvornički list u okviru Službe za informiranje, koji je osim ostalog, davao i priloge iz proizvodnje elektroda i ferolegura. Navedena izdanja su, iako lokalna, bila hvalevrijedna i korisna za tvorničko informiranje u polju metalurgije te su pisana profesionalno i jasno s korektnim novinarskim pristupom. U Splitu je u razdoblju 1967. - 1976. izlazio interni bilten Aluminij u izdanju JUGAL-a (Poslovno udruženje elektro-aluminijske industrije Split koje je činilo šest institucija), koji je prikazivao metalurške teme s ekonomskim pristupom, npr. uvoz i izvoz boksita, glinice, poluproizvoda i gotovih proizvoda, proizvodnja i potrošnja aluminija itd.

\section{Prikaz uloge i značenja gospodarskih subjekata u polju metalurgije}

Razvoj znanstvenog polja metalurgije povezan je s gospodarskim metalurškim subjektima u RH: Željezara Sisak (1938.), TLM Šibenik (1953.), TEF Šibenik (1900.), Željezara Split (1971.), brojne ljevaonice itd. ${ }^{17,37}$ Od 1960. do 1980-ih godina razvoju metalurgije u RH kao industrijske struke u RH poklanjala se velika pažnja. Željezara Sisak bila 
je najveća metalurška tvrtka u RH i jedini proizvođač bešavnih cijevi u bivšoj Jugoslaviji. Na primjer, u godini osnivanja Metalurškog odjela u Sisku (1960.) Željezara Sisak proizvela je 358,5 kt metalurških proizvoda (sirovo željezo, čelik, bešavne cijevi, odljevci), a zapošljavala je oko 6000 djelatnika. TLM Šibenik je 1960. godine proizveo 1,836 kt tekućeg aluminija i 18,401 kt Al-valjanih i prešanih proizvoda s oko 1800 zaposlenih, dok je TEF Šibenik proizveo oko 23 kt ferolegura i elektroda. Krajem 1980-ih metalurške tvrtke u RH imale su maksimalnu proizvodnju. Na primjer, Željezara Sisak je u 1988. godini proizvodila 1,72 mil. t metalurških proizvoda i zapošljavala 13742 zaposlenika, od kojih je oko je 800 s visokostručnom spremom. TLM Šibenik (činio je 90 \% Al-industrije u RH i bio je 10. izvoznik u bivšoj Jugoslaviji) je 1990. godine proizveo 74,248 kt tekućeg aluminija te 47,152 kt valjanih i prešanih Al-poluproizvoda, uz broj zaposlenika od 5482. ${ }^{37}$ Industrijska proizvodnja u 30-ak ljevaonica u RH iznosila je u 1990. godini 92,344 kt odljevaka uz 8925 zaposlenih. Ukupna prijeratna (1989.) godišnja metalurška proizvodnja poluproizvoda i proizvoda u RH je bila oko 2,5 mil. t uz oko 35000 zaposlenika, što je bitno doprinosilo društvenom bruto proizvodu. Željezara Sisak je, od svih tadašnjih tvrtki, najviše doprinijela razvoju Sisačko-moslavačke županije investirajući u otvaranje metaloprerađivačkih pogona u manje razvijena područja (Topusko, Glina, Novska, Dvor itd.) u izgradnju infrastrukture grada Siska (mostogradnja, cestogradnja, sportski objekti itd.) te je kontinuirano podizala standard svojih zaposlenika (dodjela tzv. društvenih stanova i individualnih stambenih kredita, kontinuirano i sustavno organiziranje rekreativne aktivnosti zaposlenika itd.). Nažalost, početkom 1990-ih godina uslijed ratnih razaranja u RH uveliko je poremećen rad metalurške industrije. Tijekom rata je uništena elektroliza glinice u Lukavcu (1991.), oštećena su neka postrojenja Željezare Sisak (krajem 1991. godine ukupni pad proizvodnje je 20 - 40 \%), proizvodnja odljevaka u ljevaonicama je više nego prepolovljena (42,756 kt odljevaka u 1992.) itd. Željezara Sisak je dala velik doprinos i u vrijeme Domovinskog rata i kroz uključenost u tzv. namjensku proizvodnju. Na osnovi Zakona o pretvorbi društvenih poduzeća (18. 4. 1991.) počinje prijelaz iz tzv. društvenog u privatno vlasništvo, ali na "naš način". ${ }^{19}$ Prve tri privatizacije Željezare Sisak napravile su više štete nego koristi. Željezara Split je nakon modernizacije prošla nekoliko neuspješnih privatizacija i naposljetku je odvedena u stečaj (2018.). Zbog tehnološke zastarjelosti i pritiska javnosti s ekološkog stajališta tvornica elektroda i ferolegura (TEF) Šibenik s proizvodnjom prestaje 1994. godine. Valjaonica čelika Kumrovec d. d. ugašena je 2007. godine, a istu sudbinu doživjela je i valjaonica Histria tube d. d. iz Potpićana. U TLM-u Šibenik investirano je u valjački stan (2002.) i tvrtka je prošla kroz nekoliko neuspješnih privatizacija. Također su mnoge ljevaonice neuspješno privatizirane i na kraju neke i ugašene, a one koje rade imaju bitno smanjenu godišnju proizvodnju. Današnja metalurška industrijska djelatnost u RH može se svesti na proizvodnju dijela asortimana iz proizvodnih opusa nekadašnje Željezare Sisak, TLM-a Šibenik i preostalih ljevaonica. Od bivše Željezare Sisak preostala je samo proizvodnja elektročelika u vlasništvu talijanske tvrtke Danielli od 2012. godine. Čeličana posluje pod nazivom ABS Sisak d. o. o. i ima modernu elektrolučnu peć kapaciteta 75 t za pretaljivanje čeličnog otpada u čelik, postrojenja za doradu čelika sekundarnom metalurgijom te modernizirana postrojenja za kontinuirano lijevanje čeličnih poluproizvoda. Proizvodnja sirovog čelika u 2019. godini iznosila je 69 kt čelika, uz 122 zaposlenika. Bivši pogon Nova hladna prerada čeličnih cijevi, kao dio nekadašnje Željezare Sisak, u vlasništvu je njemačke grupe Rohrwerk Maxhütte $\mathrm{GmBH}$ i posluje (od 2012.) pod nazivom Rohrwerk Maxhütte Sisak d. o. o., s djelatnošću proizvodnje čeličnih cijevi (hladnovučene i hladnovaljane-pilgerovane) i pribora, s 41 zaposlenikom u 2019. godini. Grupa Impol d. o. o. iz Slovenske Bistrice 2017. godine je kupila većinski udio u TLM-u Šibenik. U 2018. godini proizvedeno je oko 80 kt Al-proizvoda (limovi, tanke trake, trake i folije itd.). Tvrtka koja danas posluje pod nazivom Impol-TLM d. o. o. u Šibeniku ima oko 450 zaposlenika te mnogo investira u proizvodne linije za izradu proizvoda za automobilsku i avio industriju (Al-legure serije 2000 i 6000) te u ljevaonicu za proizvodnju aluminija godišnjeg kapaciteta 200 kt. U 2019. godini u RH proizvedeno je 68,385 kt željeznih i neželjeznih odljevaka. Slobodno se može konstatirati da je danas ukupna industrijska metalurška proizvodnja poluproizvoda i proizvoda u RH gotovo 10 puta manja od prijeratne, a zapošljava svega oko 4000 djelatnika.

\section{ZAHVALA}

Iskreno zahvaljujem prof. dr. sc. Josipu Črnku, umirovljenom red. prof. u trajnom zvanju Metalurškog fakulteta Sveučilišta u Zagrebu na sugestijama za prikaz razvoja znanstvenog polja metalurgija za navedeno razdoblje.

\section{Literatura}

\section{References}

1. D. Maljković, Razvitak visokoškolske izobrazbe i organiziranog rada u Sisku, Znanstveni skup: Sisak-više od 2000 godina postojanja, Sisak, 5 - 7. listopada 1989., Radovi Leksikografskoga zavoda "Miroslav Krleža", knj. 3, Zagreb, 1993., str. 23-36.

2. Z. Čepo, Željezara Sisak 1938. - 1978., treće prerađeno i dopunjeno izdanje, SOUR Metalurški kombinat "Željezara Sisak", Sisak, 1978.

3. D. Maljković, Razvoj visokoškolskog obrazovanja i organiziranog znanstvenoistraživačkig rada u Sisku, Riječi (3-4) (2001) 133-148.

4. J. Črnko, Početak visokoškolske nastave metalurgije i nastojanja za utemeljenje studija metalurgije u Hrvatskoj, Metalurgija 39 (2) (2000) 125-128.

5. Z. Čepo, Željezara Sisak 1938. - 1968., Metalurški kombinat "Željezara Sisak", Sisak, 1968.

6. Redovi predavanja Sveučilišta u Zagrebu, Sveučilište u Zagrebu, 1960./61. - 2018./19.

7. B. Derniković, Razvoj odjela u Sisku Tehnološkog fakulteta u Zagrebu, Metalurgija 5 (1) (1966) 4-56.

8. D. Maljković, Deset godina djelovanja Odjela u Sisku Tehnološkog fakulteta Sveučilišta u Zagrebu, Metalurgija 9 (1) (1970) 3-8.

9. M. Gojić, 50 godina studija metalurgije (monografija 1960. 2010.), Sveučilište u Zagrebu Metalurški fakultet, Sisak, 2010.

10. Đ. Tadić, Željezara Sisak, tvornica čelika i života, Kultura vrijednosti, Sisak, 2017.

11. J. Črnko, D. Maljković, Monografija, 40. obljetnica visokoškolske nastave metalurgije 1960. - 2000., Metalurški fakultet, Sisak, 2000.

12. Bibliografija 1961. - 1985., 2. dopunjeno i prošireno izdanje, RO Institut za metalurgiju Sisak, Sisak, 1985.

13. P. Pavlović, Pet godina postojanja Instituta za metalurgiju, Metalurgija 5 (2/3) (1966) 1-9.

14. P. Pavlović, Deset godina postojanja i rada Instituta za metalurgiju u Sisku, Čelik 7 (32) (1971) 17-21. 
15. D. Bauman, Dvadesetšest godina tradicije scanning elektronske mikroskopije u Željezari Sisak, Metalurgija 41 (4) (2002) 333-325.

16. D. Bauman, S. Gajović, Elektronska mikroskopija u Hrvatskoj (Prilozi u monografiji: M. Tuđa str. 95-110. i D. Bauman, str. 173-188.), Hrvatsko mikroskopijsko društvo, Zagreb, 2012.

17. Z. Čepo, Željezara Sisak 1938. - 1978., SOUR Metalurški kombinat "Željezara Sisak", Sisak, 1978.

18. Monografija Sveučilišta u Zagrebu 1669. - 2019., urednica M. Polić Bobić, (Prilozi u monografiji M. Gojić: Metalurški fakultet, str. 214-217; Metalurgija, str. 410-414), Sveučilište u Zagrebu, Zagreb, 2019.

19. Đ. Tadić, Talionica Caprag-Željezara Sisak 1938. - 2018., (Prilozi u knjizi: A. Prelošćan, Uloga Instituta za metalurgiju u razvoju Željezare Sisak, str. 66-73, M. Gojić, Uloga Metalurškog fakulteta u razvoju i aktivnostima Željezare Sisak, str. 165-173), Kultura vrijednosti, Sisak, 2019.

20. I. Mamuzić, Popis radova objavljenih u časopisu Metalurgija od 1962. do 2001. godine, Metalurgija 40 (izvanredni broj) (2001) 271-321.

21. J. Črnko, Bibliografija 1960. - 2010., Sveučilište u Zagrebu Metalurški fakultet, Sisak, 2013.

22. I. Mamuzić, 35 godina visokoškolske nastave i organizirane znanstvenoistraživačke djelatnosti na Metalurškom fakultetu u Sisku, Sveučilišta u Zagrebu, Metalurgija 34 (4) (1995) 175-176.

23. URL: http://www.simet.unizg.hr (31. 12. 2019.).

24. Tehnički fakulteti 1919. - 1994., Monografija u povodu 75. obljetnice tehničkih fakulteta, Sveučilište u Zagrebu, Zagreb, 1994. (prilozi: I. Galaso: Fakultet strojarstva i brodogradnje, str. 287-366; J. Crnko, Da. Maljković, Metalurški fakultet u
Sisku, str. 501-515)

25. J. Črnko, Suradnja Metalurškog fakulteta Sveučilišta u Zagrebu i Metalurškog fakulteta Tehničkog Sveučilišta u Košicama (1980. - 2005.), Metalurgija 45 (1) (2006) 71-74.

26. Fakultet strojarstva i brodogradnje Sveučilišta u Zagrebu u razdoblju od 1969. do 1979., Fakultet strojarstva i brodogradnje, Zagreb, 1979.

27. Fakultet strojarstva i brodogradnje Sveučilišta u Zagrebu u razdoblju od 1999. do 2009., Fakultet strojarstva i brodogradnje, Zagreb, 2009

28. Tehnički fakultet-50 godina 1960. - 2010., Tehnički fakultet Sveučilišta u Rijeci, Rijeka, 2010.

29. Monografija 40 godina studija strojarstva u Slavonskom Brodu 1962. - 2002., Strojarski fakultet u Slavonskom Brodu, Slavonski Brod, 2002.

30. Edicija istaknuti profesori, Miroslav Karšulin, Fakultet kemijskog inženjerstva i tehnologije i Hinus, Zagreb, 2004.

31. Lj. Vuković, Stručna knjižnica Željezare u Sisku, Kem. Ind. 53 (9) (2004) 412-414.

32. M. Grubišić Reiter, Knjižnica tvornice lakih metala, Glasnik Društva bibliotekara Split (2016. - 2017.) 14-15, 83-88.

33. J. Črnko, Časopis Metalurgija-ocrtana stvarnost metalurške struke u prošlosti i danas u Republici Hrvatskoj, Metalurgija 41 (4) (2002) 271-277.

34. URL: http://pubweb.carnet.hr/metalurg/arhiva/category/casopis-metalurgija/arhiva (31. 12. 2019.)

35. R. Franz Štern, Povodom 15-godišnjice izdavanja časopisa "Metalurgija", Metalurgija 16 (4) (1977) 41-43.

36. URL: http://bib.irb.hr (23. 2. 2020.).

37. M. Šmit, Izgradnja hrvatske aluminijske industrije, TLM Šibenik, Šibenik, 1997

\section{SUMMARY}

\section{Development the Science Scientific Field of Metallurgy in the Republic of Croatia from 1960 to 2020

\author{
Mirko Gojić
}

This work presents the development of the scientific field of metallurgy in technical sciences of the Republic of Croatia from 1960 to 2020. Development of the scientific field of metallurgy was accomplished through the Department of Metallurgy (1960-1974), and Metallurgical Engineering Department of the Faculty of Technology, University of Zagreb (1974-1978), Zagreb Institute for Light Metals (1949-1968), Sisak Institute for Metallurgy (1961-1978), Faculty of Metallurgy of the Sisak Iron and Steel Works (1979-1991), and Faculty of Metallurgy as part of the University of Zagreb (1991-). Development of the scientific field of metallurgy is closely connected to the metallurgical industry of the Republic of Croatia (Sisak Iron and Steel Works, Sibenik Light Metals Factory, numerous foundries, etc.) and professional libraries. Presented are the education, scientific research, professional, publishing, and journalistic activities in the scientific field of metallurgy. In addition, the contribution of other higher school institutions and professional societies is presented. Up to December 31, 2019, achieved were 763 academic titles and 34 doctor-of-science degrees in the field of metallurgy at the University of Zagreb. During the 1960-2020 period, published were over 3000 scientific and professional papers in domestic and international journals, as well as in proceedings of international and domestic conferences. As a result of professional activities, produced were over 1000 studies, numerous professional reports for metallurgy and similar companies, about twenty patents registered, etc. During this period, published were also several monographies from the field of metallurgy, over fifty books and university textbooks, seven proceedings (1999-2006), and eleven books of abstracts from international casting conferences, as well as numerous university and internal scripts, etc.

\section{Keywords}

Metallurgy, Department for Metallurgy, Institute for Metallurgy, Institute of Light Metals, Faculty of Metallurgy University of Zagreb 